\title{
The Role of Non-Canonical Hsp70s (Hsp110/Grp170) in Cancer
}

\author{
Graham Chakafana *,+ and Addmore Shonhai *(D) \\ Department of Biochemistry, University of Venda, Private Bag X5050, 0950 Thohoyandou, South Africa \\ * Correspondence: graham.chakafana@uct.ac.za (G.C.); addmore.shonhai@univen.ac.za (A.S.) \\ † Present Address: Department of Medicine, University of Cape Town, Faculty of Health Sciences, Observatory, \\ 7925 Cape Town, South Africa.
}

check for updates

Citation: Chakafana, G.; Shonhai, A. The Role of Non-Canonical Hsp70s (Hsp110/Grp170) in Cancer. Cells 2021, 10, 254. https://doi.org/ $10.3390 /$ cells10020254

Academic Editor: Boris Margulis Received: 16 December 2020

Accepted: 26 January 2021

Published: 28 January 2021

Publisher's Note: MDPI stays neutral with regard to jurisdictional claims in published maps and institutional affiliations.

\begin{abstract}
Although cancers account for over $16 \%$ of all global deaths annually, at present, no reliable therapies exist for most types of the disease. As protein folding facilitators, heat shock proteins (Hsps) play an important role in cancer development. Not surprisingly, Hsps are among leading anticancer drug targets. Generally, Hsp70s are divided into two main subtypes: canonical Hsp70 (Escherichia coli Hsp70/DnaK homologues) and the non-canonical (Hsp110 and Grp170) members. These two main Hsp70 groups are delineated from each other by distinct structural and functional specifications. Non-canonical Hsp70s are considered as holdase chaperones, while canonical Hsp70s are refoldases. This unique characteristic feature is mirrored by the distinct structural features of these two groups of chaperones. Hsp110/Grp170 members are larger as they possess an extended acidic insertion in their substrate binding domains. While the role of canonical Hsp70s in cancer has received a fair share of attention, the roles of non-canonical Hsp70s in cancer development has received less attention in comparison. In the current review, we discuss the structure-function features of non-canonical Hsp70s members and how these features impact their role in cancer development. We further mapped out their interactome and discussed the prospects of targeting these proteins in cancer therapy.
\end{abstract}

Keywords: Hsp110; Grp170; non-canonical Hsp70; chaperone; cancer

\section{Introduction}

Cancer accounts for approximately one sixth of total global annual deaths [1]. The most widely used interventions against cancer, such as chemotherapy and radiotherapy, are not always effective due to treatment-induced cellular, genetic and biochemical changes that often confer treatment resistance [2]. This, therefore, urgently necessitates the need to identify novel anticancer targets. Apart from their role as molecular chaperones, heat shock proteins (Hsps) play an important role in various cancer signaling pathways such as tumorigenesis, carcinogenesis and apoptosis [3,4]. As such, the role of Hsps as cancer biomarkers is increasingly becoming apparent.

Several proteins play crucial roles in the key hallmarks of tumorigenesis (Figure 1). It is therefore not surprising that upset of cellular proteostasis is one of the several factors that could drive tumor cell proliferation and metastasis. Tumor cells therefore rely on robust protein folding machinery to sustain conformational stabilities of the proteins required for their proliferation. As signaling molecules, Hsp members are intimately linked to cancer progression (Figure 1). For example, a small Hsp (sHsp), Hsp27 and Hsp70 inhibit release of cytochrome c, caspase 3 and 9 from the mitochondria, thus causing cells to evade apoptosis $([5,6]$, Figure 1). Several studies have indeed demonstrated the inactivation of the caspase cascade facilitated by Hsp27 binding with caspase 3 and cytochrome $c$ released from mitochondria [7,8]. Furthermore, Hsp27 also induces resistance to chemotherapy by sequestrating cytochrome $\mathrm{c}$ upon its release from mitochondria into cytosol [8]. On the other hand, Hsp70 blocks apoptosis by binding to Bax to suppress its translocation to mitochondria [9], thus reducing permeabilization of the mitochondrial membrane, consequently, this inhibits release of mitochondrial apoptogenic molecules, such as cytochrome c [10]. 


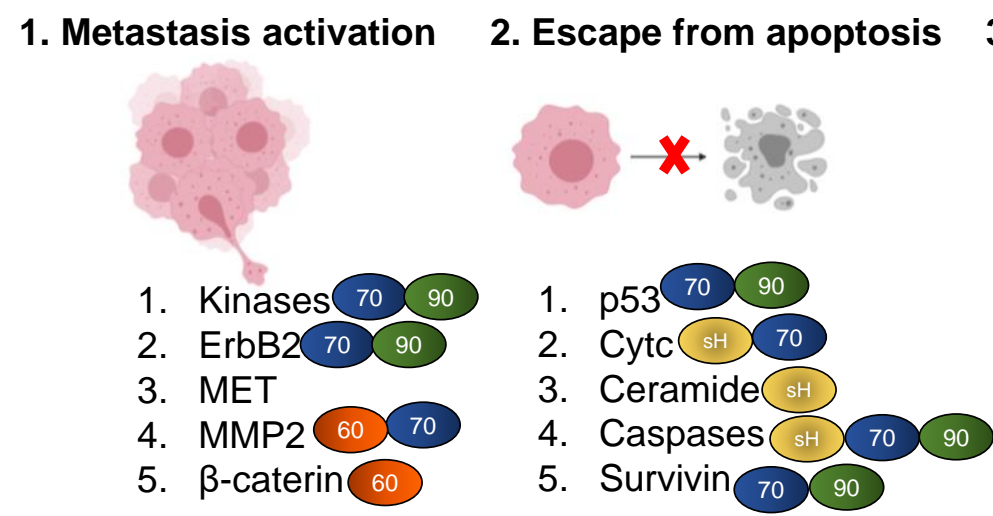

\section{Evasion of anti-growth signals}

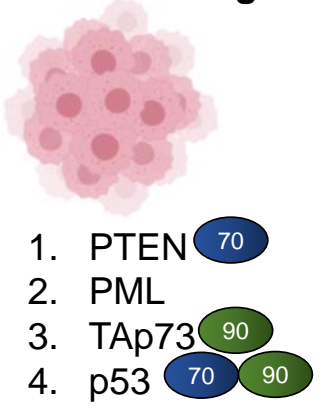

4. Evasion of senescence

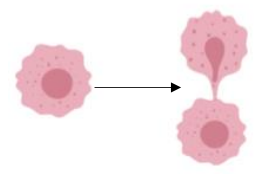

1. Telomerase 90

2. p2160

3. Myosin 7090

4. p27 7090

5. $\mathrm{p} 537090$
5. Uncontrolled angiogenesis

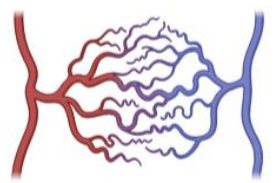

1. $\mathrm{HIFa} \rightarrow 7090$

2. PRKD2

3. NOS 6070

4. VEGF 7090

5. bFGF
6. Sustained cell proliferation

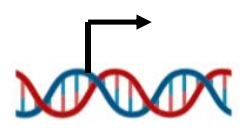

1. $\mathrm{AKT1} 6070$

2. IKK 90

3. ERK 90

4. EGFR 7090

5. FGF

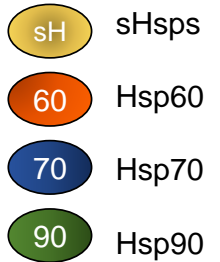

Figure 1. The proteomic landscape of the hallmarks of cancer: The processes of metastasis, uncontrolled angiogenesis, evasion of anti-growth signals, escape from apoptosis, cell proliferation and evasion of senescence are all crucial to tumor cell growth. Each of these processes is regulated by several proteins that play important roles in the respective signaling pathways. As chaperones, sHsps, Hsp70, Hsp90 and Hsp60 associate with several proteins that regulate cancer signaling pathways.

Since they are constantly in a state of proteotoxic stress, cancer cells exploit Hsps to protect themselves against the toxic effects of aberrant oncoproteins, genomic instability, hypoxia and acidosis $[11,12]$. High Hsp expression levels are associated with poor prognosis and treatment resistance in cancer patients, since Hsps protect tumor cells from therapeutic stressors such as radiation and cytotoxic chemotherapy [13]. Indeed, overexpression of Hsps has been observed in a wide range of cancers, including breast, endometrial, ovarian, gastric, colon, lung and prostate cancer [13-16]. Due to their ability to oversee proteostasis, Hsps facilitate the folding and maturation of proteins involved in cancer signaling pathways (Figure 1). Therefore, elevated Hsp levels are often associated with tumor progression $[4,17-19]$. In addition to their proteostatic functions, some Hsps are translocated to the cell surface where they function as receptors, thus serving as conduits that regulate several cancer signaling pathways including cell proliferation and invasion [20]. The presence of Hsps on cancer cell surfaces is an aspect that warrants further research, as it presents opportunities for development of novel chemotherapeutic strategies. In addition, Hsps also act as chaperokines that trigger an immune response against oncogenic cells [21]. In a previous study, the Hsp70-derived peptide, TKD, was reported to stimulate natural killer 
(NK) cells which then targeted tumor cells harboring Hsp70 on their membranes [22,23]. This further represents a prospective Hsp-mediated anticancer intervention.

It has been demonstrated that inhibition of Hsp90 induces degradation of oncogenic proteins $[24,25]$. Not surprisingly, Hsp90 promotes the conformational maturation of several oncogenic signaling proteins, including steroid receptors such as p53 [26,27] and tyrosine kinases such as ErBb2 ([28], Figure 1). Additionally, the expression of some oncogenes in the absence of Hsp70 may result in cell inactivation [29]. This underscores the importance of Hsps in modulating oncogenic processes. Remarkably, Hsp70 and Hsp27 have both been shown to interact directly with protein intermediates of the apoptosis pathway [30-32]. Since it is highly expressed in malignant tumors and on the surface of tumor cells, Hsp70 typically serves as a biomarker of poor prognosis in cancer patients. Notably, the roles of the Hsp70 and Hsp90 in cancer development are becoming subjects of immense research interest [33,34]. Knockdown of the heat shock factor 1 (HSF1) gene coupled with Hsp90 inhibition was shown to disrupt cancer cell proliferation in vitro and tumor growth in vivo [35]. Furthermore, the same study demonstrated that HSF1 knockdown combined with HSP90 inhibition not only facilitated the degradation of oncogenic proteins, but also induced cancer cell apoptosis and decreased activity of the ERK pathway [35]. Consequently, most Hsp-targeted anticancer treatment efforts have primarily focused on Hsp70 and its ER homologue, Grp78 as well as Hsp90 [36-38]. A kinase inhibitor, sorafenib, used in the treatment of renal cell carcinoma and hepatocellular carcinoma, is an example of an Hsp70 targeting anticancer drug which functions to reduce the expression of Grp78 in cancer cells [39]. Thus, small molecules that modulate Hsp expression as well as those that inhibit their activity constitute possible anticancer agents.

\section{Hsp110/Grp170}

The human genome encodes a total of 17 Hsp70s, four of which are Hsp110 or Grp170 protein homologues ([40]; Table 1). Grp170 proteins are closely related to the Hsp110 family of proteins which occur in the endoplasmic reticulum (ER) and are primarily induced by glucose deprivation [41]. Both Grp170 and Hsp110 proteins constitute a non-canonical clade of the Hsp70 family. Hence, in our narrative, except where it distinguishes the function of these two proteins within their distinct cellular localization, we use the terms Hsp110 and Grp170 interchangeably, as the two chaperones are generally similar in structure and function.

Hsp70s are typically characterized by an N-terminal nucleotide binding domain (NBD) and a C-terminal substrate binding domain (SBD), connected by a linker (Figure 2). Although the NBDs of canonical and non-canonical Hsp70s exhibit relatively high sequence conservation, their SBDs are more divergent [42]. In spite of their high conservation, members of the Hsp70 family are characterized by unique signature motifs that define their functional specialization within cells. Notably, Hsp110s are marked by extended acidic insertions located within their substrate binding domain, SDB- $\beta$ and SBD- $\alpha$ subunits ([43], Figure 2A). Additionally, Hsp110s possess linker segments that are distinct from canonical Hsp70s [44,45]. Hsp110/Grp170 families also harbor unique TEDWYLEE motifs which distinguish them from canonical Hsp70s [41]. Although at present the actual functions of these motifs have not yet been determined, they are thought to facilitate co-chaperone or client protein binding in light of their location in the SBD. Interestingly, human Hsp110/Grp170 group members are delineated from each other by unique TEDWYLEE motifs [42]. 
A.

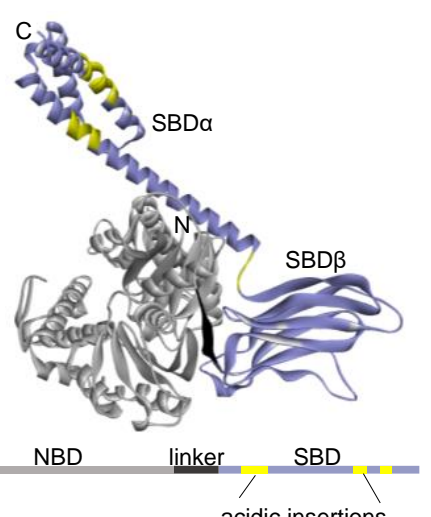

C.

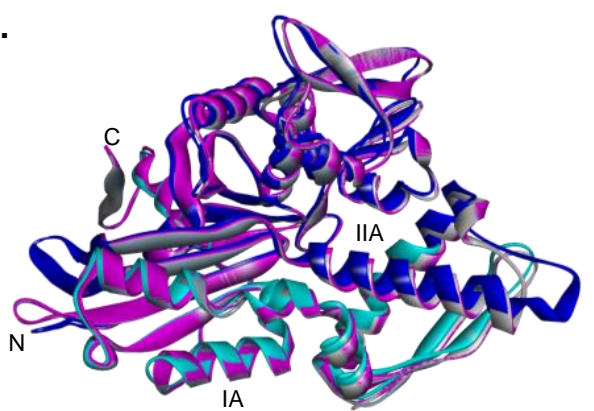

B.

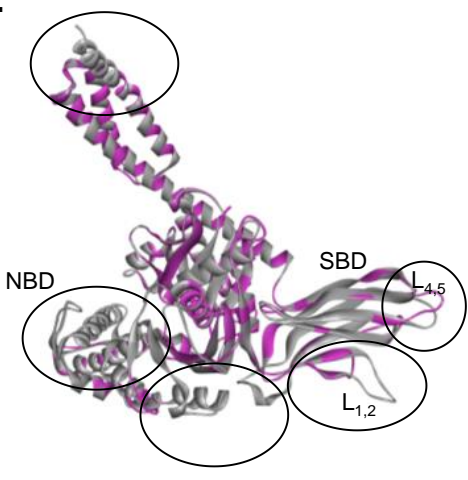

D.

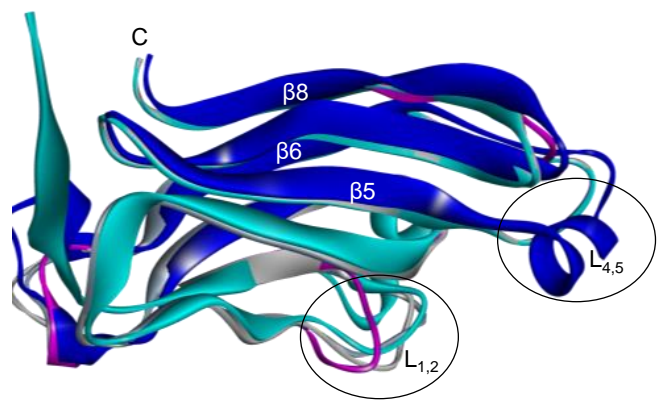

E.

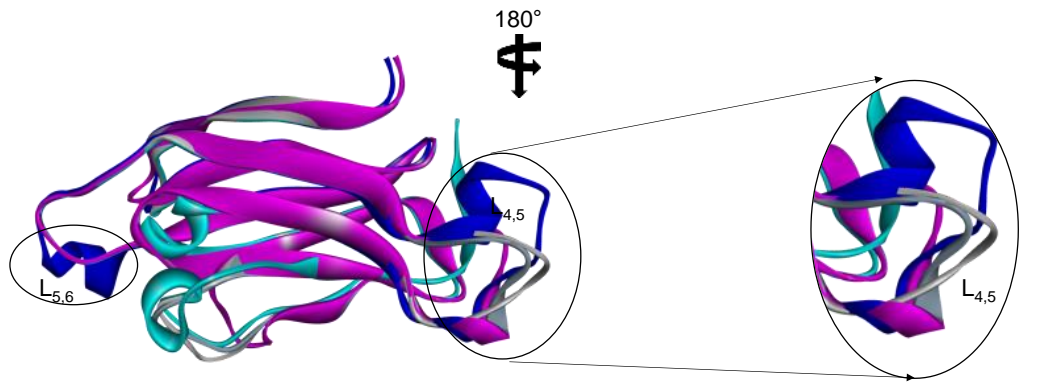

Figure 2. General structural features of human Hsp110s: (A) Structure of Hsp110 showing major features, including the unique acidic insertions in the substrate binding domain (SBD) $\propto$ region. (B) Comparative structural analyses of a canonical Hsp70 (HspA1, purple) and an Hsp110 (HspH1, grey). Variations are predicted to occur within $\mathrm{L}_{1,2}$ and $\mathrm{L}_{4,5}$. (C) The nucleotide binding domains (NBDs) of human HspH1 (cyan), HspH2 (purple), HspH3 (grey) and Grp170 (blue) show high conservation. (D) The SBDs of human HspH1 (cyan), HspH2 (purple), HspH3 (grey) and Grp170 (blue) show variation within the SBD $\beta$ segments. (E) Major variations are predicted to occur at loops L4,5 and L5,6 of the SBD $\beta$ segments of human HspH1 (cyan), HspH2 (purple), HspH3 (grey) and Grp170 (blue).

Table 1. Hsp110/Grp170 proteins of human origin.

\begin{tabular}{ccccc}
\hline $\begin{array}{c}\text { Protein } \\
\text { (Accession Number) }\end{array}$ & $\begin{array}{c}\text { Size } \\
\mathbf{( k D a )}\end{array}$ & Localization & $\begin{array}{c}\text { Stress Inducible } \\
\text { (Yes/No) }\end{array}$ & Cellular Functions \\
\hline $\begin{array}{c}\text { 1. HspH1 } \\
\text { (Q92598) }\end{array}$ & 97 & $\begin{array}{c}\text { Cytosol, nucleus, } \\
\text { endocytic vesicle }\end{array}$ & Yes & $\begin{array}{c}\text { Apoptosis suppression, aggregation } \\
\text { suppression, nucleotide exchange factor (NEF) }\end{array}$ \\
\hline $\begin{array}{c}\text { 2. HspH3 } \\
\text { (O95757) }\end{array}$ & 95 & Cytosol, nucleus & Yes & $\begin{array}{c}\text { Ellicits humoral immune responses in } \\
\text { leukemia patients }\end{array}$ \\
\hline $\begin{array}{c}\text { 3. HspH2 } \\
\text { (P34932) }\end{array}$ & 95 & $\begin{array}{c}\text { Cytosol, extracellular } \\
\text { exosome }\end{array}$ & ND & Implicated in spermatogenesis \\
\hline $\begin{array}{l}\text { 4. Grp170 } \\
\text { (Q9Y4L1) }\end{array}$ & 111 & ER & Yes & Aggregation suppression, NEF \\
\hline
\end{tabular}


Hsp110s possess seven $\beta$ strands in the SBD, while canonical Hsp70s possess a total of eight $\beta$ strands [43]. Using three-dimensional models, we also observed structural variations within the loop regions $\mathrm{L}_{1,2}$ and $\mathrm{L}_{4,5}$ of a human canonical Hsp70 (HspA1A) and Hsp110 (HspH1) (Figure 2). Structural variations arising within these SBD sections potentially account for the functional delineations of Hsp110s in comparison to canonical Hsp70s. Generally, the SBD of Hsp110s preferentially binds peptide substrates harboring aromatic residues in contrast to canonical Hsp70s, which preferentially bind substrates enriched with aliphatic residues of approximately seven residues in length [50]. Structural variations in loops of Hsp70 are important for the function of the chaperone. For example, loops $\mathrm{L}_{1,2}$ and $\mathrm{L}_{3,4}$ located in $\mathrm{SBD} \beta$ and are thought to regulate substrate binding specificity [51]. It was recently reported that most variations in the SBD segments of Hsp70s not only occur within the loop regions of the substrate binding cleft but also in the helical lid $(\mathrm{SBD} \alpha)$ sections [42]. Indeed, the SBD $\alpha$ segment of Hsp110 is endowed with acidic insertions that are absent in the canonical isoform (Figure 2). This suggests that the lid regulates functional specificity of Hsp70 [52]. Hsp110 is reported to possess significantly higher substrate binding efficiency than canonical Hsp70 [53] and this could be attributed to its longer SBD $\alpha$ lid segment. Furthermore, the yeast Hsp110 homologue, Sse1, was shown to exhibit unique peptide-binding preferences from the canonical Hsp70 homologue (Ssa1), suggesting that Hsp70 and Hsp110 substrates do not serve entirely overlapping functions [53]. The study demonstrated that Hsp110 does not have notable affinity for a typical Hsp70 peptide substrate (enriched with aliphatic residues), thus suggesting that Hsp70s and Hsp110s possess distinct peptide recognition motifs [53].

Using three-dimensional structural modeling tools (Biova Discovery Studio 4.5), we noted some structural differences between the four human Hsp110 isoforms (HspH1, $\mathrm{HspH} 2$, HspH3, Grp170). Generally, the NBD segments of the 4 non-canonical Hsp70s exhibit high conservation (Figure 2C). Conservation of the NBD of these non-canonical Hsp70s is important in light of the role of this motif in regulating nucleotide exchange of their canonical Hsp70 counterparts. However, notable variations exist within their substrate binding domains of the Hs110 types [51]. It is therefore conceivable that these variations observed within the individual loop segments may account for distinct substrate selectivity. As such, each of the Hsp110s may play distinct roles in chaperoning proteins involved in cancer signaling pathways. In comparison to Hsp110, Grp170 exhibits a unique alpha helical section within $\mathrm{L}_{4,5}$ and $\mathrm{L}_{5,6}$ (Figure 2C). Thus, as an endoplasmic reticulum-based chaperone, Grp170 is possibly functionally adapted for its role in the ER. Consequently, it is also conceivable that Grp170 chaperones a specialized set of oncogenic proteins located within the ER.

Functionally, Hsp110/Grp170 subfamily members bind misfolding polypeptides, to prevent their aggregation $[44,54,55]$. This way they maintain denatured protein substrates in a soluble, folding-competent state before handing them over to canonical Hsp70 for folding into the native state [56,57]. In addition, canonical Hsp70 releases its substrate in the presence of ATP and stably binds substrate in the ADP-bound state [58]. On the other hand, the chaperone function of Hsp110/Grp170 chaperones is not regulated by nucleotides, therefore, Hsp110 remains bound to substrate even in the ATP state [50]. Thus, Hsp110/Grp170 members are more effective holdase chaperones than their canonical Hsp70 counterparts $[44,50,53]$. Hence canonical Hsp70s serve as refoldases while Hsp110/Grp170 members are buffers against proteostatic stress [59,60]. Hsp110/Grp170 also function as nucleotide exchange factors (NEFs) of canonical Hsp70 [60,61].

Cancer cells are subjected to several forms of physiological insults, including anticancer interventions-induced stress, immune response, elevated reactive oxygen species, enhanced hypoxic and acidic conditions $[62,63]$. Under these conditions, the stress buffering role of Hsp110 becomes apparent. In vitro studies have indeed shown that Hsp110 is significantly more efficient at recognizing denatured proteins than canonical Hsp70 and is thus is more capable of salvaging misfolding-prone proteins during stress $[43,50]$. This feature may possibly be attributed to the fact that Hsp110 possesses a longer lid segment 
which enables it to more effectively bind substrates than canonical Hsp70. Similarly, the Plasmodium falciparum Hsp110 displayed better aggregation suppression activity than its canonical isoform in the presence of excess ATP [44]. Since the tumor milieu is generally in a critical state with respect to energy production [64], the ATP-independent nature of Hsp110 holdase chaperone function may be a crucial factor for cancer cell development. Indeed, Hsp110 was previously shown to be conformationally more stable to thermal stress than canonical Hsp70 [65]. This further confirms Hsp110 as a buffer against extreme cellular conditions that adversely impact proteostatic integrity. Notably, unlike its canonical counterpart, Hsp110 is largely allosterically dormant on account of its rigid linker, connecting the NBD to the SBD [66]. As such, Hsp110 would be expected to be conformationally more stable as a holdase chaperone in the wake of physiological changes [45].

\section{Hsp110 Roles in Cancer Pathogenesis}

Several factors that upset proteostasis, such as drug pressure, $\mathrm{pH}$ and temperature changes, threaten the survival of malignant cells. In response to physiological stress, cancer cells activate cytoprotective adaptive pathways in which Hsp110 expression is upregulated. Indeed, Hsp110 expression is reportedly upregulated in various cancers including melanoma, prolactinoma, pituitary adenoma, breast cancer, colorectal cancer, pancreatic cancer, thyroid cancer, esophageal cancer, lung cancer, bladder cancer, islet cell tumor, gastric cancer, lymphoma, seminoma and hepatocellular carcinomas [67-72]. Furthermore, high Hsp110 expression is a poor prognostic factor for patients with melanoma, esophageal cancer, gastric cancer, tongue squamous cell carcinoma, colorectal cancer, non-Hodgkin lymphoma, MDS or AML [67,73,74]. This may imply that suppression of Hsp110 expression in cancer cells may threaten the survival of tumor cells.

In cancer cells, Hsp110 may possibly facilitate protein stability and function by preventing aggregation of misfolded proteins as well as = maintaining protein conformation to enable ligand binding. A recent model proposed a possible role for Hsp110 in suppressing aggregation of $\alpha$-synuclein [75]. The upregulation of $\alpha$-synuclein is thought to contribute to aggressive phenotypes of meningiomas via the Akt/mTOR pathway, thus highlighting a possible role for Hsp110 in the development of malignant meningiomas by regulating the conformational stability of $\alpha$-synuclein [76]. It is possible that $\alpha$-synuclein may represent several Hsp110 clients implicated in malignant meningiomas, thus highlighting a crucial role of Hsp110 in shepherding conformational stability of the cancer cell proteome. Whether interception of Hsp110 function would abrogate progression of cancer remains to be established, however, such a prospect is worth investigating further.

A previous study demonstrated that $\mathrm{HspH} 1$ is a component of the $\beta$-catenin degradation complex which is implicated in cancer signaling [77]. HspH1 overexpression has also been shown to correlate with elevated nuclear $\beta$-catenin protein levels and upregulation of Wnt genes [77] implicated in cancer. As such, HspH1 upregulation accompanied with hyperactivation of Wnt signaling may pose as important prognostic biomarkers of cancer $[78,79]$. Notably, HspH1 overexpression is a prognostic biomarker that overall correlates with poor survival in breast cancer patients [77]. Whereas Hsp110 overexpression correlates with enhanced nuclear $\beta$-catenin protein levels and upregulation of Wnt gene, its depletion promoted hyperphosphorylation and degradation of $\beta$-catenin [77]. In light of the roles of Wnt and $\beta$-catenin in regulating transcription, the role of Hsp110 in overseeing the fate of these two molecules makes its role in cancer development apparent.

As a chaperone, Hsp110 confers thermotolerance to mammalian cells [43]. Furthermore, Hsp110 is involved in STAT3 phosphorylation in the cytosol, thereby promoting cell proliferation ([72], Figure 3). STAT3 is constitutively activated in several cancers and is thought to play a critical role in tumor growth and metastasis [80-83]. STAT3 also regulates several signaling pathways such as cellular proliferation, invasion and angiogenesis, which are all critical for metastasis $[84,85]$. As such, through its role in STAT3 phosphorylation, Hsp110 may regulate apoptosis and cancer development. Indeed, Hsp110 has been shown to protect cells from stress-induced apoptosis $[71,86]$. RNA interference targeting the 
Hsp110 gene induced apoptosis in cancer cells, thus further pointing to an indirect role of this chaperone in the inhibition of apoptosis [87].
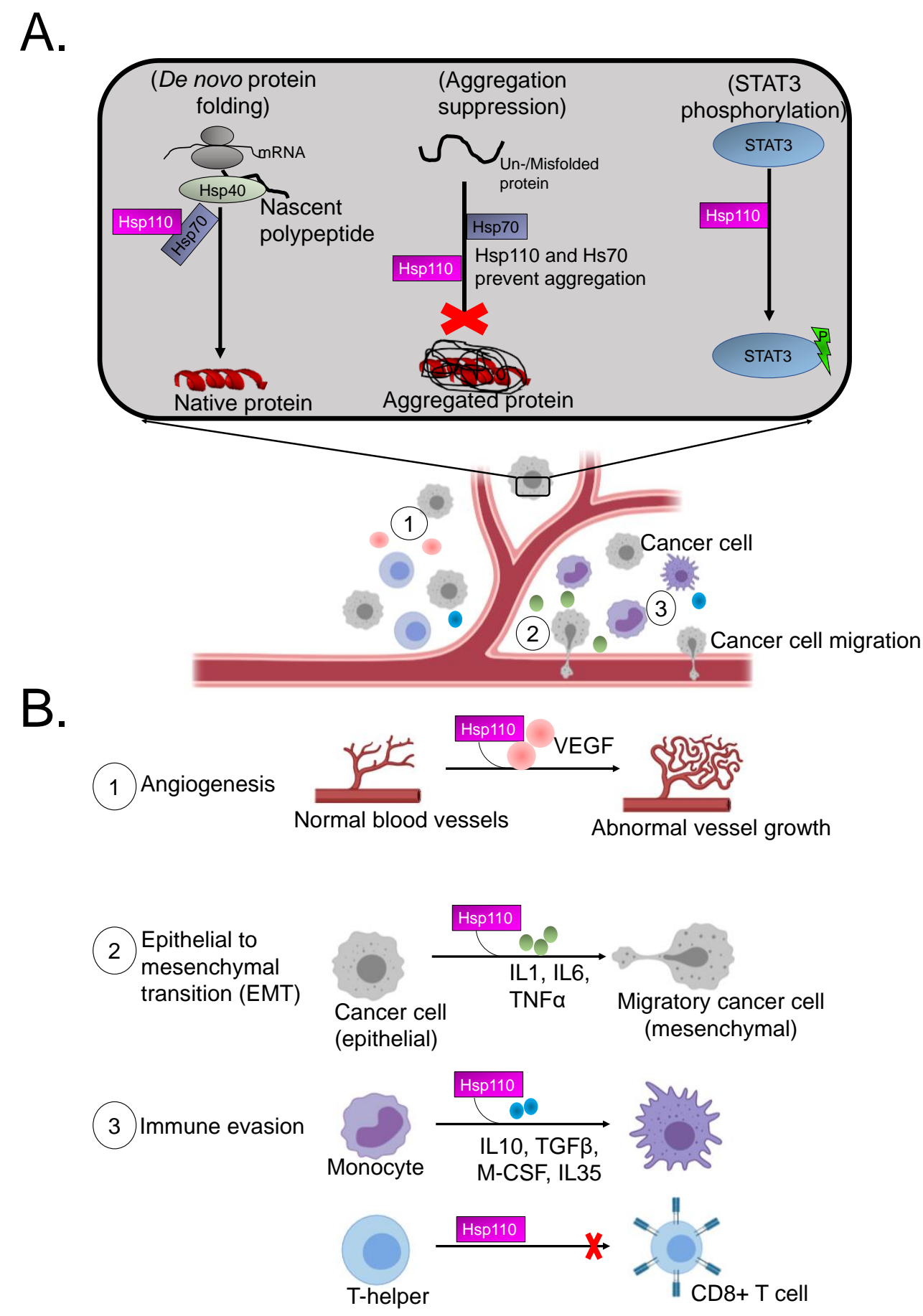

Figure 3. Roles of Hsp110 in cancer cells: (A) Hsp110 co-operates with Hsp70 complexed to its co-chaperone Hsp40 to facilitate folding of nascent polypeptides in tumor cells. Hsp110 also independently suppresses aggregation of oncogenic proteins and regulates functional competence of molecules such as STAT3 whose phosphorylation it facilitates, thereby promoting tumor cell proliferation. (B) Hsp110 modulates metastasis in tumour cells via interaction with VEGF leading to abnormal angiogenesis (1). Hsp110 is also involved in EMT via association with proinflammatory cytokines (2) and in immune evasion pathways (3) which ultimately result in metastasis. 
Aberrant cell migration is a major determinant of metastasis, leading to the development of malignant tumors [88]. As such, metastasis is the leading cause of cancer-related deaths [89]. Cancer cell migration and invasion into surrounding vasculature is a crucial initial step in metastasis [90]. Cell migration is a complex process characterized by several steps which include epithelial mesenchymal transition (EMT), abnormal angiogenesis and immune evasion ([91], Figure 3). During metastasis, cancer cells break free from the primary tumor to join the circulatory system, thus enabling colonization of distant organs. Interestingly, several protein molecules within the tumor microenvironment are associated with metastasis (Figure 3). Notably, Hsp110/Grp170 proteins play important roles in regulating activity of some proteins involved in these signaling pathways. Using a murine model, Manjili et al. [92] demonstrated that Hsp110 induces dendritic cells (DCs) to upregulate the expression of proinflammatory cytokines such as IL-6, TNF- $\alpha$ and IL-12. Similarly, tumor cells engineered to produce a secretable form of Grp170 triggered upregulated TNF- $\alpha$ secretion from DCs [93]. IL- 6 and TNF- $\alpha$ play key roles in EMT, as previously demonstrated $[92,94,95]$. Upon EMT activation, tumor epithelial cells lose their cell polarity and adhesion properties to gain migratory and invasive properties, becoming mesenchymal cells $[96,97]$. Interestingly, the role of EMT in various cancers, including prostate, lung, liver, pancreatic and breast cancers, has been established $[98,99]$. Since Hsp110 is implicated in modulating proteins involved in EMT, its potential role in the development of metastasis could be inferred.

Angiogenesis is important in metastasis, as the growth and spread of neoplasms largely depends on the establishment of an adequate blood supply. Notably, Hsp110 potentially modulates angiogenesis. It has been established that Hsp110 co-operates with sHsps (such as HspB5) to suppress protein aggregation under stress conditions [100]. sHsp family members are known to modulate activity of the proangiogenic factor, VEGF, which induces structurally and functionally abnormal vasculature formation [101]. Hsp110 may therefore indirectly play a central role in angiogenesis and may thus constitute a promising target for novel anticancer therapy. T cells, monocytes and other immune cells are known to exert antimetastatic functions [102]. During the metastasic cascade, crosstalk between tumor cells and immune cells triggers immune evasion. This pathway is modulated by several anti-inflammatory cytokines such as transforming growth factor $\beta$ (TGF $\beta$ ), IL10 and IL35 [103,104]. Although the direct association of these cytokines with Hsp110 is yet to be experimentally validated, Hsp110 likely plays a key role in the folding of these proteins by canonical Hsp70s. Indeed, it has previously been reported that Hsp70s associate with and modulate function of some anti-inflammatory cytokines [105].

Hsp110 generally confers cytoprotection by functioning as a stress buffer which prevents stress-induced apoptosis. Previous studies have suggested that Hsp110's antiapoptotic and chaperone roles are crucial for survival of tumor cells against the action of anticancer drugs or hypoxia [87]. Furthermore, Hsp110 upregulation suppresses cancer cell apoptosis by inhibiting the activation of caspase 9 and caspase 3 by blocking cytochrome c release from mitochondria $[87,106,107]$. Interestingly, the role of Hsp110 in activated B-cell diffuses large B-cell lymphoma (ABC-DLBCL) survival mechanisms has been also been established [108]. Hsp110 overexpression in ABC-DLBCL cell lines induces increased NF-kB signaling, thereby suggesting a tight interplay between Hsp110 and the NF-kB pathway [108]. This is particularly important since ABC-DLBCL tumors rely on sustained NF-kB activation for survival. At the intracellular level, Hsp110 possesses antiaggregation properties and also participates in the folding of nascent polypeptides or misfolded proteins in cells ([44], Figure 3). Further studies to elucidate the roles for Hsp110/Grp170 in cancer development are thus urgently required.

\section{The Role of the ER Resident, Grp170 Chaperone in Cancer Pathophysiology}

Since the ER is a critical organelle that facilitates several aspects of protein synthesis, including post-translational modification and subsequent folding, Grp170 plays a particularly significant role in cellular proteostasis. Like other Hsp110s, Grp170 generally exhibits 
dual functions; as an NEF for Grp78 (the ER Hsp70) and in aggregation suppression of secretory or transmembrane proteins in the ER [36]. The cytoprotective activity of intracellular Grp170 provides a survival benefit in cancer cells during tumor progression or metastasis [36]. Accumulating evidence demonstrates that Grp170 can directly bind to a variety of incompletely folded protein substrates in vivo in a nucleotide-independent fashion $[109,110]$. As such, Grp170 remains tightly bound to peptide substrates in both the ATP and ADP states, making it an efficient buffer against cellular stress [110].

Stress factors including glucose and oxygen deprivation within the tumor microenvironment are known to activate a Grp170-mediated unfolded protein response (UPR) to promote tumor cell survival [111]. Grp170 is thought to be a potential prognostic factor of breast cancer, since altered Grp170 levels correlate with different stages of tumor invasiveness $[112,113]$. Due to its ability to chaperone several proteins associated with cancer signaling pathways, Grp170 appears to possess pro-tumor activity ([114,115], Figure 3). In addition, Grp170 involvement in angiogenesis of tumors has been described through its ability to chaperone the major proangiogenic factor vascular endothelial growth factor (VEGF) $[116,117]$. Similarly, an antisense approach was used to demonstrate Grp170's ability to reduce tumorigenicity in a prostate cancer model by blocking secretion of matured VEGF [117]. Grp170 has also been shown to associate with matrix metalloproteinase-2 (MMP-2) thereby promoting tumor invasion [118].

In as much as additional studies are necessary to glean a better understanding of the precise mechanistic contribution of the non-canonical Hsp70s in tumorigenesis, their chaperoning function appears to account for their pro-tumor activity. Complete proteomic studies on the involvement of Hsp110/Grp170 in cancer pathophysiology are worth exploring. Notably, Hsp110/Grp170 are predicted to interact with a large complement of proteins that are implicated in cancer development (Figure 3).

\section{Identification of Potential Unique Proteomic Signatures of Hsp110/Grp170}

We predicted the interactome of Hsp110/Grp170 homologues using the STRING 10.5 database ([119], http://string-db.org/). The predicted interactomes of the proteins revealed possible associations of these chaperones with several proteins implicated in tumorigenesis (Table 2). Generally, while there were overlapping interaction partners between the various Hsp110 forms, we noted that the chaperones were also marked with possibly unique interactomes (Figure 4). For instance, $\mathrm{HspH} 2$ and Grp170 were predicted to interact with a large complement of protein modifying enzymes as opposed to HspH1 and HsapH3 (Figure 4). Additionally, Grp170 also seemed to interact with a large complement of proteins that are involved in several other roles including protein translocation. The observed variations in interactomes may possibly arise from the structural variations and ER localization of Grp170, which makes it functionally specialized for binding ER proteins. Seemingly, the different Hsp110 isoforms play unique roles in chaperoning proteins involved in the different cancer signaling pathways as described below.

Table 2. Predicted interaction of Hsp110/Grp170 with cancer-associated proteins.

\begin{tabular}{ll}
\hline \multicolumn{1}{c}{ Protein } & \multicolumn{1}{c}{ Function } \\
\hline $\begin{array}{ll}\text { 1. GAK-cyclin G (kinase) } \\
\text { 2. CPS1(Carbamoyl-phosphate synthase) }\end{array}$ & $\begin{array}{l}\text { Associates with cyclin G and CDK5 and is involved in the uncoating of } \\
\text { clathrin-coated vesicles by Hsc70. }\end{array}$ \\
\hline $\begin{array}{l}\text { 3. EDEM3 (ER degradation-enhancing } \\
\text { alpha-mannosidase-like protein 3 }\end{array}$ & $\begin{array}{l}\text { Involved in the urea cycle and plays an important role in removing excess } \\
\text { ammonia from the cell. }\end{array}$ \\
\hline $\begin{array}{l}\text { 4. CHORDC1 (Cysteine and histidine-rich } \\
\text { domain-containing protein 1) }\end{array}$ & $\begin{array}{l}\text { Accelerates ER-associated degradation (ERAD) of glycoproteins } \\
\text { by proteasomes. }\end{array}$ \\
\hline
\end{tabular}


Table 2. Cont.

\begin{tabular}{l} 
Protein \\
\hline 1. NUP188 (Nucleoporin) \\
\hline 2. C11 orf73 \\
\hline
\end{tabular}

3. NUP37 (Nucleoporin)

4. RANBP2 (E3 SUMO-protein ligase)

\begin{tabular}{lc}
\multicolumn{1}{c}{ Function } & Score \\
\hline HspH3 Interaction Partners & 0.937 \\
\hline May function as a component of the nuclear pore complex (NPC). & 0.931 \\
\hline Acts as a specific nuclear import carrier for HSP70. & 0.926
\end{tabular}
progression and chromosome segregation.

Facilitates SUMO1 and SUMO2 conjugation, (Ran-GTP,

karyopherin)-mediated protein import. Component of the nuclear export pathway.

Essential for normal nucleocytoplasmic transport of proteins and mRNAs, plays a role in the establishment of nuclear-peripheral chromatin compartmentalization in interphase, and in the mitotic spindle checkpoint

5. TPR (Nucleoprotein TPR) signaling during mitosis.

7. RAE1 (mRNA export factor) Plays a role in mitotic bipolar spindle formation. May function in nucleocytoplasmic transport.

May be essential for embryogenesis. Nucleoporins may be involved both in binding and translocating proteins during nucleocytoplasmic transport.

8. NUP155 (Nuclear pore complex protein) Essential for normal nucleocytoplasmic transport of proteins and mRNAs. Involved in the quality control and retention of unspliced mRNAs in the nucleus.

9. NUP153 (Nuclear pore complex protein)

May serve as a docking site in the receptor-mediated import of substrates across the nuclear pore complex.

10. NUP214 (Nuclear pore complex protein)

Plays a role in mitotic cell cycle progression by regulating centrosome segregation, centriole maturation and spindle orientation. It might be involved in protein recruitment to the centrosome after nuclear breakdown.

11. NUP62 (Nuclear pore glycoprotein)

During renal development, regulates podocyte migration and proliferation through SMAD4 signaling.

Component of the Nup107-160 subcomplex of the nuclear pore complex (NPC) required for normal kinetochore microtubule attachment, mitotic progression and chromosome segregation.

13. NUP43 (Nucleoporin) Essential component of nuclear pore complex.

Involved in poly (A)+ RNA transport.

Involved in poly(A)+ RNA transport.

0.904

Interacts with regulatory proteins of cell cycle progression including CDKN1B.

14. NUP88 (Nuclear pore complex protein)

15. NUP133 (Nuclear pore complex protein)

16. NUP50 (Nuclear pore complex protein)

Required for the assembly of peripheral proteins into the NPC.

17. NUP107 (Nuclear pore complex protein) Plays a key role in de novo assembly and insertion of NPC in the nuclear envelope. Required for NPC and nuclear envelope assembly, possibly by forming a link between the nuclear envelope membrane and soluble nucleoporins, thereby anchoring the NPC in the membrane.

18. NDC1 (Nucleoporin)

Essential for nuclear pore assembly and fusion, as well as structural integrity.

0.901

19. NUP210 (Nuclear pore membrane glycoprotein)

Can play the role of both NPC structural components and of docking or interaction partners for transiently associated nuclear transport factors.

20. NUP35 (Nucleoporin)

Essential component of the nuclear pore complex (NPC). May be involved in anchoring components of the pore complex to the pore membrane.

21. POM121 (Nuclear envelope pore membrane protein)

22. POM121C (Nuclear envelope pore membrane protein)

Essential component of the nuclear pore complex (NPC). May be involved in anchoring components of the pore complex to the pore membrane.

23. NUP160 (Nucleoporins) Involved in poly(A)+ RNA transport.

24. NUPL2 (Nucleoporin-like protein) Required for the export of mRNAs containing poly(A) tails from the nucleus into the cytoplasm. 
Table 2. Cont.

\begin{tabular}{|c|c|c|}
\hline Protein & Function & Score \\
\hline 26. GAK (Cyclin-G-associated kinase) & $\begin{array}{l}\text { Involved in the uncoating of clathrin-coated vesicles by Hsc70 in } \\
\text { non-neuronal cells. }\end{array}$ & 0.874 \\
\hline 27. STIP1 (Stress-induced-phosphoprotein) & $\begin{array}{l}\text { Mediates the association of the molecular chaperones HSPA8/HSC70 } \\
\text { and HSP90. }\end{array}$ & 0857 \\
\hline $\begin{array}{l}\text { 28. EDEM3 (ER degradation-enhancing } \\
\text { alpha-mannosidase-like protein 3) }\end{array}$ & $\begin{array}{l}\text { Involved in endoplasmic reticulum-associated degradation (ERAD) of } \\
\text { glycoproteins by proteasomes, by catalyzing mannose. }\end{array}$ & 0.792 \\
\hline \multicolumn{3}{|c|}{ HspH2 Interaction Partners } \\
\hline 1. SNCA (Alpha-synuclein) & $\begin{array}{l}\text { Induces fibrillization of microtubule-associated protein tau. Reduces neuronal } \\
\text { responsiveness to various apoptotic stimuli, leading to a decreased caspase } \\
3 \text { activation. }\end{array}$ & 0.965 \\
\hline 2. $\mathrm{C} 11$ orf73 & Acts as a specific nuclear import carrier for HSP70. & 0.964 \\
\hline 3. NUP62 (Nuclear pore glycoprotein) & $\begin{array}{l}\text { Plays a role in mitotic cell cycle progression by regulating centrosome } \\
\text { segregation, centriole maturation and spindle orientation. It might be } \\
\text { involved in protein recruitment to the centrosome after nuclear breakdown. }\end{array}$ & 0.944 \\
\hline 4. RANBP2 (E3 SUMO-protein ligase) & $\begin{array}{l}\text { Facilitates SUMO1 and SUMO2 conjugation, transport factor (Ran-GTP, } \\
\text { karyopherin)-mediated protein import via the F-G repeat-containing domain } \\
\text { which acts as a docking site for substrates. Component of the nuclear } \\
\text { export pathway. }\end{array}$ & 0.940 \\
\hline 5. TPR (Nucleoprotein) & $\begin{array}{l}\text { Essential for normal nucleocytoplasmic transport of proteins and mRNAs, } \\
\text { plays a role in the establishment of nuclear-peripheral chromatin } \\
\text { compartmentalization in interphase, and in the mitotic spindle checkpoint } \\
\text { signaling during mitosis. }\end{array}$ & 0.935 \\
\hline 6. NUP37 (Nucleoporin) & $\begin{array}{l}\text { Component of the Nup107-160 subcomplex of the nuclear pore complex } \\
\text { (NPC) required for normal kinetochore microtubule attachment, mitotic } \\
\text { progression and chromosome segregation. }\end{array}$ & 0.929 \\
\hline 7. OLR1 (Oxidized low-density lipoprotein receptor) & $\begin{array}{l}\text { Mediates the recognition, internalization and degradation of oxidatively } \\
\text { modified low-density lipoprotein (oxLDL) by vascular endothelial cells. }\end{array}$ & 0.927 \\
\hline 8. NUP155 (Nuclear pore complex protein) & $\begin{array}{l}\text { Essential for embryogenesis. Nucleoporins may be involved both in binding } \\
\text { and translocating proteins during nucleocytoplasmic transport. }\end{array}$ & 0.925 \\
\hline 9. NUP54 (Nucleoporin p54) & $\begin{array}{l}\text { Component of the nuclear pore complex, a complex required for the } \\
\text { trafficking across the nuclear membrane. }\end{array}$ & 0.921 \\
\hline 10. ССТ2 (T-complex protein 1 subunit beta) & $\begin{array}{l}\text { Molecular chaperone; assists the folding of proteins upon ATP hydrolysis. } \\
\text { Known to play a role, in vitro, in the folding of actin and tubulin. }\end{array}$ & 0.917 \\
\hline 11. RAE1 (mRNA export factor) & $\begin{array}{l}\text { Plays a role in mitotic bipolar spindle formation. Binds mRNA. May function } \\
\text { in nucleocytoplasmic transport. }\end{array}$ & 0.916 \\
\hline 12. NUP107 (Nuclear pore complex protein) & $\begin{array}{l}\text { Required for the assembly of peripheral proteins into the NPC. May anchor } \\
\text { NUP62 to the NPC. }\end{array}$ & 0.916 \\
\hline 13. NUP214 (Nuclear pore complex protein) & $\begin{array}{l}\text { May serve as a docking site in the receptor-mediated import of substrates } \\
\text { across the nuclear pore complex. }\end{array}$ & 0.915 \\
\hline 14. NUP88 (Nucleoporins) & Essential component of nuclear pore complex. & 0.915 \\
\hline 15. NUP93 (Nuclear pore complex protein) & $\begin{array}{l}\text { During renal development, regulates podocyte migration and proliferation } \\
\text { through SMAD4 signaling. }\end{array}$ & 0.914 \\
\hline 16. AHSA1 (Activator of Hsp90 ATPase) & $\begin{array}{l}\text { Activates the ATPase activity of HSP90AA1 leading to increase in its } \\
\text { chaperone activity. }\end{array}$ & 0.913 \\
\hline 17. NUP153 (Nuclear pore complex protein) & $\begin{array}{l}\text { Essential for normal nucleocytoplasmic transport of proteins and mRNAs. } \\
\text { Involved in the quality control and retention of unspliced mRNAs in } \\
\text { the nucleus. }\end{array}$ & 0.912 \\
\hline 18. NDC1 (Nucleoporin) & $\begin{array}{l}\text { Plays a key role in de novo assembly and insertion of NPC in the } \\
\text { nuclear envelope. }\end{array}$ & 0.907 \\
\hline 19. NUP205 (Nuclear pore complex protein) & Plays a role in the nuclear pore complex (NPC) assembly and/or maintenance. & 0.907 \\
\hline 20. NUP160 (Nuclear pore complex protein) & Involved in poly(A)+ RNA transport. & 0.907 \\
\hline
\end{tabular}


Table 2. Cont.

\begin{tabular}{lll}
\hline \multicolumn{1}{c}{ Protein } & \multicolumn{1}{c}{ Function } & Score \\
\hline 21. NUP50 (Nuclear pore complex protein) & Interacts with regulatory proteins of cell cycle progression. & 0.906 \\
\hline 22. NUP35 (Nucleoporin) & $\begin{array}{l}\text { Can play the role of both NPC structural components and of docking or } \\
\text { interaction partners for transiently associated nuclear transport factors. }\end{array}$ & 0.903 \\
\hline 23. AAAS (Nucleoporins) & $\begin{array}{l}\text { Plays a role in the normal development of the peripheral and central } \\
\text { nervous system. }\end{array}$ & 0.903
\end{tabular}
nervous system.

Immunophilin protein with PPIase. Plays a role in the intracellular trafficking of heterooligomeric forms of steroid hormone receptors between cytoplasm and nuclear compartments. Acts also as a regulator of microtubule dynamics by inhibiting MAPT/TAU ability to promote microtubule assembly.

25. NUPL2 (Nucleoporin-like protein)

Required for the export of mRNAs containing poly(A) tails from the nucleus into the cytoplasm.

26. NUP85 (Nuclear pore complex protein) Required for spindle assembly during mitosis.

27. NUP188 (Nucleoporin)

May function as a component of the NPC.

28. NUP210 (Nuclear pore membrane glycoprotein)

Nucleoporin essential for nuclear pore assembly and fusion, nuclear pore spacing, as well as structural integrity.

29. POM121C (Nuclear envelope pore membrane protein)

Essential component of the nuclear pore complex (NPC).

30. POM121 (Nuclear envelope pore membrane protein)

Essential component of the nuclear pore complex (NPC).

31. GAK (Cyclin-G-associated kinase)

Involved in the uncoating of clathrin-coated vesicles by Hsc70 in non-neuronal cells.

32. CPS1 (Carbamoyl-phosphate synthase)

Involved in the urea cycle; plays an important role in removing excess ammonia from the cell.

May function as a regulatory ATPase and be related to secretion/protein trafficking process.

33. CLPB (Caseinolytic peptidase B protein)

Regulates many processes including metabolism, proliferation, cell survival, growth and angiogenesis. AKT is responsible of the regulation of glucose uptake.

35. CCT5 (T-complex protein 1 subunit epsilon)

Acts as a tumor suppressor in many tumor types; induces growth arrest or apoptosis depending on the physiological circumstances and cell type. Involved in cell cycle regulation as a trans-activator that acts to negatively

36. TP53 (Cellular tumor antigen p53) regulate cell division by controlling a set of genes required for this process.

37. CCT3 (T-complex protein 1 subunit gamma) Known to play a role, in vitro, in the folding of actin and tubulin.

Promotes the GTP-dependent binding of aminoacyl-tRNA to the A-site of ribosomes during protein biosynthesis. Forms a complex that acts as a $\mathrm{T}$ helper 1 (Th1) cell-specific transcription factor and binds the promoter of

38. EEF1A1 (Elongation factor 1-alpha 1) IFN-gamma to directly regulate its transcription and is thus involved importantly in Th1 cytokine production.

\begin{tabular}{lll}
\hline 39. CCT4 (T-complex protein 1 subunit delta) & Known to play a role, in vitro, in the folding of actin and tubulin. & 0.851 \\
\hline 40. CCT6A (T-complex protein 1 subunit zeta) & Known to play a role, in vitro, in the folding of actin and tubulin. & 0.848 \\
\hline 41. NR3C1 (Glucocorticoid receptor) & Has transcriptional repression activity. & 0.845 \\
\hline 42. APAF1 (Apoptotic protease-activating factor 1) & $\begin{array}{l}\text { Mediates the cytochrome c-dependent autocatalytic activation of procaspase } 9 \\
\text { (Apaf-3), leading to the activation of caspase } 3 \text { and apoptosis. }\end{array}$ & 0.841 \\
\hline $\begin{array}{l}\text { 43. CFTR (Cystic fibrosis transmembrane } \\
\text { conductance regulator) }\end{array}$ & $\begin{array}{l}\text { Regulation of epithelial ion and water transport and fluid homeostasis. } \\
\text { Mediates the transport of chloride ions across the cell membrane. }\end{array}$ \\
\hline $\begin{array}{l}\text { 44. SGT1 } \\
\text { 45. OLA1 (Obg-like ATPase) }\end{array}$ & $\begin{array}{l}\text { May play a role in ubiquitination and subsequent proteasomal degradation of } \\
\text { target proteins. }\end{array}$ \\
\hline
\end{tabular}


Table 2. Cont.

\begin{tabular}{|c|c|c|}
\hline Protein & Function & Score \\
\hline \multicolumn{3}{|c|}{ Grp170 Interaction Partners } \\
\hline 1. PDIA4 (Protein disulphide-isomerase) & Belongs to the protein disulphide isomerase family. & 0.993 \\
\hline 2. SIL1 (Nucleotide exchange factor) & $\begin{array}{l}\text { Functions as a nucleotide exchange factor for the ER lumenal } \\
\text { chaperone HSPA5. }\end{array}$ & 0.989 \\
\hline 3. SEC63 (Translocation protein) & $\begin{array}{l}\text { Required for integral membrane and secreted preprotein translocation across } \\
\text { the endoplasmic reticulum membrane. }\end{array}$ & 0.962 \\
\hline 4. P4HB (Protein disulphide-isomerase) & $\begin{array}{l}\text { May cause structural modifications of exofacial proteins. Inside the cell, seems } \\
\text { to form/rearrange disulphide bonds of nascent proteins. }\end{array}$ & 0.954 \\
\hline 5. CALR (Calcium-binding chaperone) & $\begin{array}{l}\text { Promotes folding, oligomeric assembly and quality control in the endoplasmic } \\
\text { reticulum (ER) via the calreticulin/calnexin cycle. Interacts transiently with } \\
\text { almost all of the monoglucosylated glycoproteins that are synthesized in the ER. }\end{array}$ & 0.954 \\
\hline 6. PDIA6 (Protein disulphide-isomerase A6) & $\begin{array}{l}\text { Negatively regulates the unfolded protein response (UPR) through binding to } \\
\text { UPR sensors such as ERN1, which in turn inactivates ERN1 signaling. }\end{array}$ & 0.950 \\
\hline $\begin{array}{l}\text { 7. MANF (Mesencephalic astrocyte-derived } \\
\text { neurotrophic factor) }\end{array}$ & $\begin{array}{l}\text { Inhibits cell proliferation and endoplasmic reticulum (ER) stress-induced cell } \\
\text { death (182 aa). }\end{array}$ & 0.946 \\
\hline 8. CANX (Calcium-binding protein) & $\begin{array}{l}\text { May act in assisting protein assembly and/or in the retention within the ER of } \\
\text { unassembled protein subunits. It seems to play a major role in the quality } \\
\text { control apparatus of the ER by the retention of incorrectly folded proteins. }\end{array}$ & 0.934 \\
\hline 9. PDIA3 (Protein disulphide-isomerase A3) & Belongs to the protein disulphide isomerase family. & 0.924 \\
\hline 10. SEC61A1 (Protein transport protein) & $\begin{array}{l}\text { Plays a crucial role in the insertion of secretory and membrane polypeptides } \\
\text { into the ER. Required for assembly of membrane and secretory proteins. }\end{array}$ & 0.906 \\
\hline 11. CRELD2 & Cysteine rich with EGF-like domains & 0.901 \\
\hline 12. SLC9C2 & Sodium/hydrogen exchange; Involved in $\mathrm{pH}$ regulation. & 0.876 \\
\hline 13. ANKRD45 & Ankyrin repeat domain-containing protein. & 0.876 \\
\hline 14. ERLEC1 (Endoplasmic reticulum lectin 1) & $\begin{array}{l}\text { May function in endoplasmic reticulum quality control and endoplasmic } \\
\text { reticulum-associated degradation (ERAD) of both non-glycosylated proteins } \\
\text { and glycoproteins. }\end{array}$ & 0.876 \\
\hline 15. CLGN (Calmegin) & $\begin{array}{l}\text { Functions during spermatogenesis as a chaperone for a range of client } \\
\text { proteins that. are important for sperm adhesion onto the egg zona pellucida } \\
\text { and for subsequent penetration of the zona pellucida. }\end{array}$ & 0.868 \\
\hline $\begin{array}{l}\text { 16. DDOST } \\
\text { (Dolichyl-diphosphooligosaccharide-protein } \\
\text { glycosyltransferase) }\end{array}$ & $\begin{array}{l}\text { Essential subunit of the N-oligosaccharyl transferase (OST) complex which } \\
\text { catalyzes the transfer of a high mannose oligosaccharide from a lipid-linked } \\
\text { oligosaccharide donor to an asparagine residue. Required for } \\
\text { efficient N-glycosylation. }\end{array}$ & 0.866 \\
\hline 17. SEC61A2 (Protein transport protein) & $\begin{array}{l}\text { Plays a crucial role in the insertion of secretory and membrane polypeptides } \\
\text { into the ER. It is required for assembly of membrane and secretory proteins. }\end{array}$ & 0.826 \\
\hline 18. OS9 & $\begin{array}{l}\text { Functions in endoplasmic reticulum (ER) quality control and ER-associated } \\
\text { degradation (ERAD). }\end{array}$ & 0.803 \\
\hline 19. SYVN2 (E3 ubiquitin-protein ligase synoviolin) & $\begin{array}{l}\text { Component of the endoplasmic reticulum quality control (ERQC) system. } \\
\text { Protects cells from ER stress-induced apoptosis. }\end{array}$ & 0.786 \\
\hline 20. SDF2L1 & Stromal cell derived factor 2 like 1. & 0.783 \\
\hline 21. SEL1L & $\begin{array}{l}\text { Plays a role in the endoplasmic reticulum quality control (ERQC) system. } \\
\text { Plays a role in LPL maturation and secretion. Required for normal } \\
\text { differentiation and survival of pancreatic cells. }\end{array}$ & 0.783 \\
\hline 22. CDNF (Cerebral dopamine neurotrophic factor) & $\begin{array}{l}\text { Prevents the 6- hydroxydopamine (6-OHDA)-induced degeneration of } \\
\text { dopaminergic neurons. Also prevents the degeneration of } \\
\text { dopaminergic neurons. }\end{array}$ & 0.777 \\
\hline $\begin{array}{l}\text { 23. EDEM3 (ER degradation-enhancing } \\
\text { alpha-mannosidase-like protein 3) }\end{array}$ & $\begin{array}{l}\text { Involved in endoplasmic reticulum-associated degradation (ERAD). } \\
\text { Accelerates the glycoprotein ERAD by proteasomes. }\end{array}$ & 0.773 \\
\hline 24. SLC35B2 & $\begin{array}{l}\text { May indirectly participate in activation of the NF- kappa-B and } \\
\text { MAPK pathways. }\end{array}$ & 0.768 \\
\hline 25. GAK (Cyclin-G-associated kinase) & $\begin{array}{l}\text { Is involved in the uncoating of clathrin-coated vesicles by Hsc70 in } \\
\text { non-neuronal cells. }\end{array}$ & 0.752 \\
\hline
\end{tabular}


A.

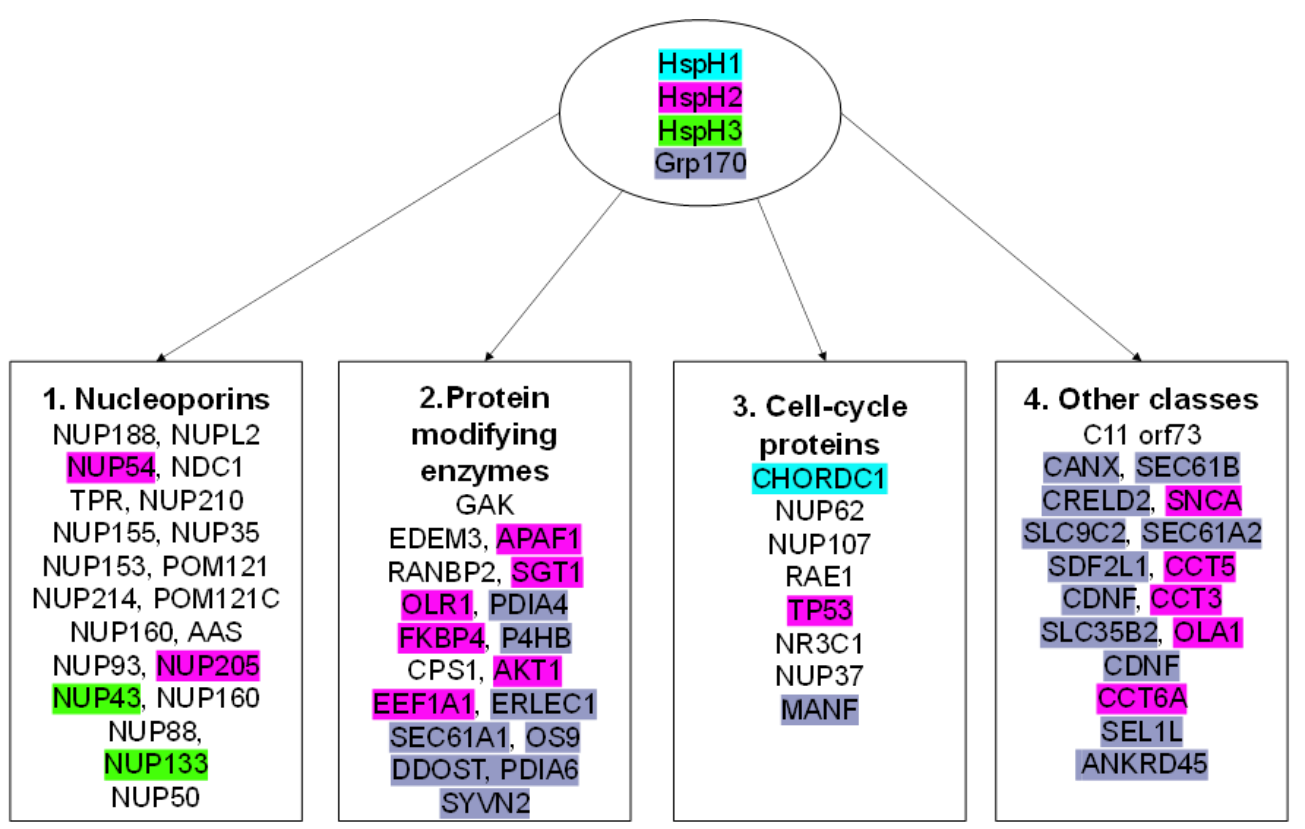

B.
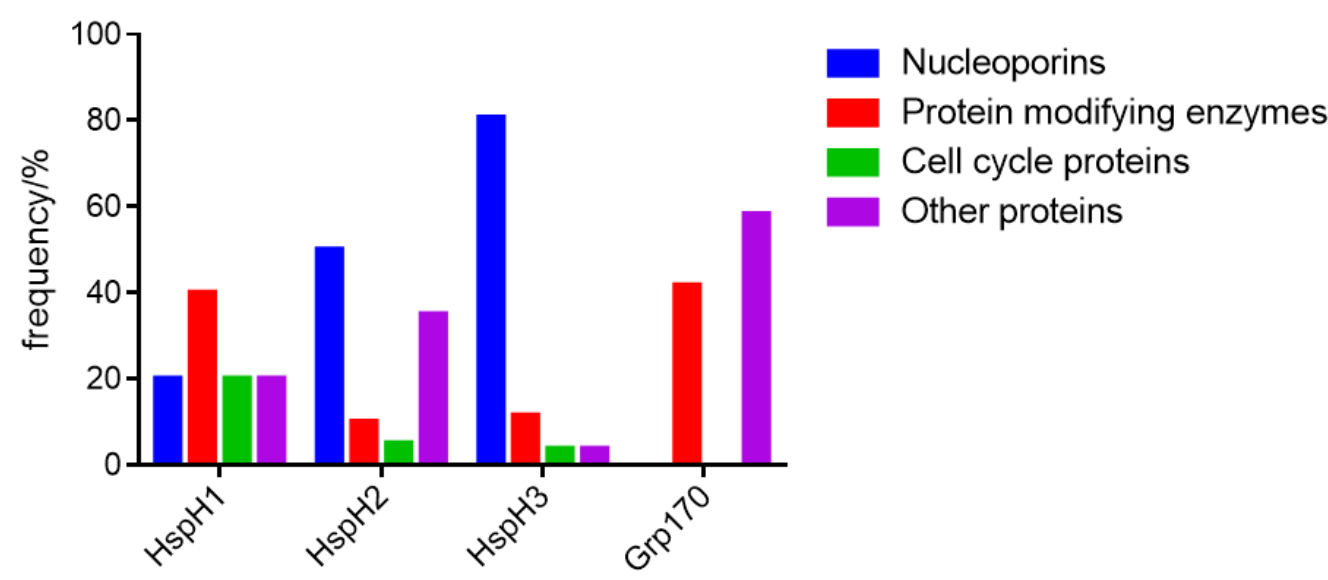

Cell cycle proteins

Other proteins

Figure 4. Predicted clients of Hsp110 and Grp170 members: (A) The predicted clientele of HSP110 and Grp170 are shown. Client proteins that are unique to each Hsp110/Grp170 type are shown highlighted in blue (HspH1), purple (HspH2), green (HspH3) and green (Grp170). Client proteins that are shared by more than one Hsp110/Grp170 type are not highlighted. Predictions were conducted using STRING database at a cut off score of 0.75. (B) Bar graph showing relative frequencies of clients of Hsp110 and Grp170 chaperones. While $\mathrm{HspH} 1, \mathrm{HspH} 2$ and $\mathrm{HspH} 3$ are generally predicted to associate with nucleoporins and cell-cycle regulating proteins, Grp170 interacts with a large complement of protein modifying enzymes and proteins involved in other functions such as translocation.

Notably, all the Hsp110 isoforms (HspH1, HspH2, HspH3 and Grp170) were predicted to associated with the cyclin G dependent kinase, GAK (Table 2). Cyclin dependent kinases are key regulatory enzymes that are involved in cell proliferation, which is an important hallmark of tumorigenesis. Previously, it has been established that GAK enhances the androgen receptor (AR) transcriptional response in androgen-independent prostate cancer [120]. Furthermore, GAK has been proposed as a druggable anticancer candidate that has broad therapeutic applications across numerous tumor types, including breast and colorectal cancers [121]. Given its important role in maintaining GAK in a functional state, it is therefore conceivable that Hsp110s have a crucial role in promoting tumorigenesis.

Intriguingly, $\mathrm{Hsp} 110$ isoforms, $\mathrm{HspH} 3$ and $\mathrm{HspH} 2$, were predicted to interact with a large complement of nucleoporins as opposed to Grp170 and HspH1. Nucleoporins are 
components of nuclear pore complexes (NPCs) which are huge macromolecular assemblies in the nuclear envelope, through which bidirectional cargo movement between the nucleus and cytoplasm occurs [122]. Several nucleoporins are linked to cancer, mostly in the context of chromosomal translocations, which encode nucleoporin chimeras [123]. Tumor cells are thought to exploit specific properties of nucleoporins to deregulate transcription, chromatin boundaries and essential transport-dependent regulatory circuits [123]. The nucleoporin POM121, which is predicted to interact with HspH3 and Hsp2, has reportedly been linked to prostate cancer [124]. POM121 has also been reported as a novel prognostic marker of oral squamous cell carcinoma [125]. It is therefore plausible that $\mathrm{HspH} 3$ and $\mathrm{HspH} 2$ play crucial roles in chaperoning POM121 in cancer progression. Several other nucleoporins, including translocated promoter region (TPR), Nup98 and Nup214, were also predicted to interact with $\mathrm{HspH} 3$ and $\mathrm{HspH} 2$ (Table 2). These proteins have previously been described as "promiscuous nucleoporins" due to their unique ability to associate with various partners to produce a variety of oncogenic fusion proteins [126]. Thus, HspH3and $\mathrm{HspH} 2$-directed therapies may also hold prospects in prostate cancer intervention.

It was also predicted that HspH3 and Grp170 interact with EDEM3, whose upregulation is linked to thyroid cancer (Table 2). It remains to be established if the enhanced expression of EDEM3 associated with thyroid cancer is accompanied with a concomitant increase in $\mathrm{HspH} 3$ levels. The possibility of $\mathrm{HspH} 3$ as a biomarker for thyroid cancer is therefore worth exploring. Previous evidence suggests that, SUMOylation is implicated in cancer cell signaling and gene networks that regulate carcinogenesis, proliferation, metastasis and apoptosis [127]. Interestingly, $\mathrm{HspH} 3$ was predicted to interact with the SUMO protein, RANBP2 (Figure 4, Table 2). This implies that the chaperone potentially modulates SUMOylation in cells, possibly resulting in tumorigenesis.

Sec proteins form part of the heterotrimeric Sec61 and the dimeric Sec62/Sec63 complexes located in the ER membrane [128]. These complexes are thought to play a central role in the translocation of nascent and newly synthesized precursor polypeptides into the ER. Notably, Sec overexpression has been linked to cancer. Interestingly, several Sec proteins were predicted to interact with Hsp110 and Grp170 chaperones (Table 2). In a study conducted by Diwadkar et al. [129], interbreeding of Sec $t R N A$ transgenic mice with a model of prostate cancer resulted in accelerated development of prostatic intraepithelial neoplasia (PIN) and more aggressive high-grade lesions.

\section{Heroes or Villains: The Role of Heat Shock Proteins in Preventing Cancer Progression}

Primarily, as chaperones, the role of Hsps is to assess the folding status of a protein towards assisting its refolding or, alternatively, to channel it towards degradation. In this way, Hsps may either hide metabolic consequences of mutations or they may expose them. More intriguingly, Hsps are thought to serve as buffers of protein mutations, i.e., they enable otherwise mutated proteins to fold into their functional conformations [130]. Thus, depending on the pathway that their respective substrates are implicated in, Hsps may promote or obstruct cancer development. However, on the balance it appears that malfunctioning of chaperones leads to general deregulation of several metabolic pathways, including those involved in signal transduction [130].

Mechanistically, Hsp110 functions as part of a protein assembly (chaperome) in concert with several other chaperones such as Hsp70 and sHsps to facilitate cellular proteostasis (Figure 5). Hsp110 chaperome complexes constitute multimolecular scaffolds that exhibit functional versatility to cater to the sustained function of the oncoprotein complement of cancer cells [131]. Interestingly, cell stress is thought to further stabilize chaperome complexes by reducing the dynamic nature of chaperone-chaperone/co-chaperone interactions ([131]; Figure 5). Alterations in protein-protein interaction networks are thought to be at the core of malignant transformation [132]. It is also thought that stress may remodel the proteome by both enhancing of interaction affinity of the chaperone complement as well as by switching interaction partner combinations, thus leading to proteome-wide connectivity dysfunctions [133]. How stress modulates a chaperome to alter protein-protein interactions 
in cancer remains yet to be fully explored. It was recently established that N-glycosylation of the ER-resident Hsp90 chaperone, Grp94, during stress led to global remodelling of cellular protein networks [133].

A.

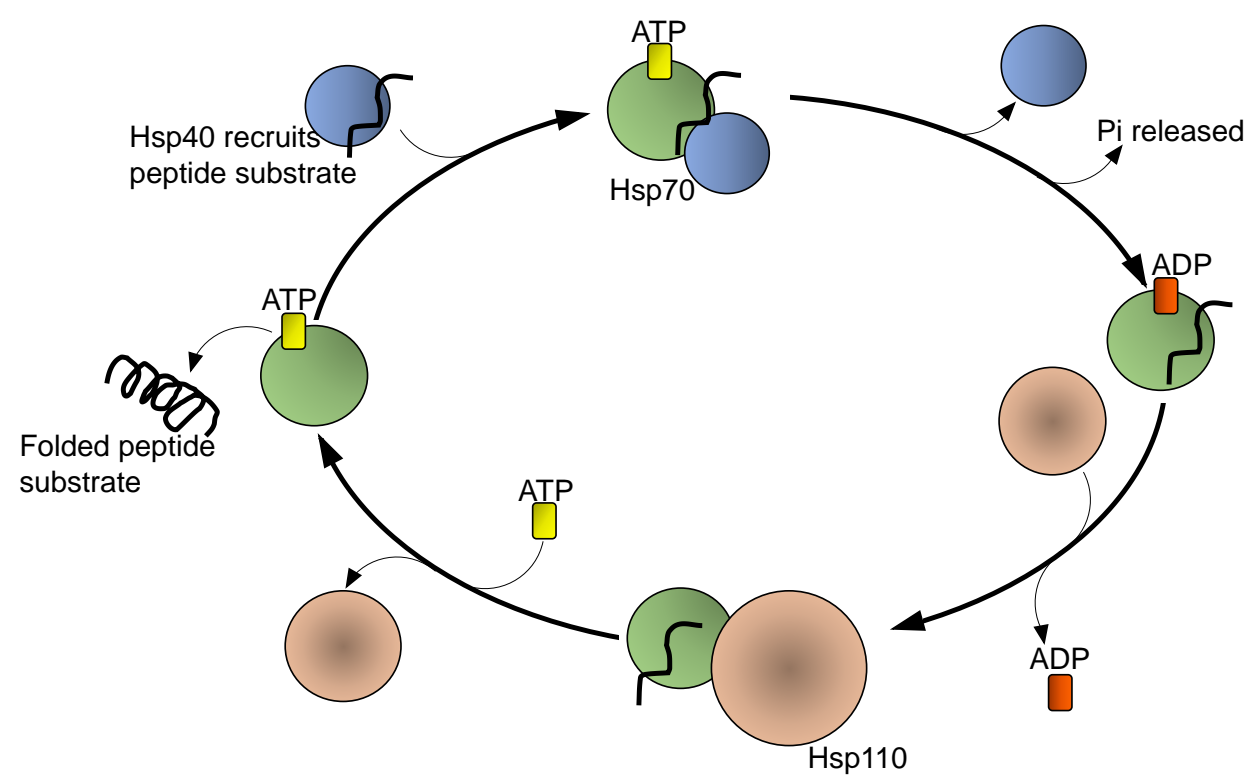

B.

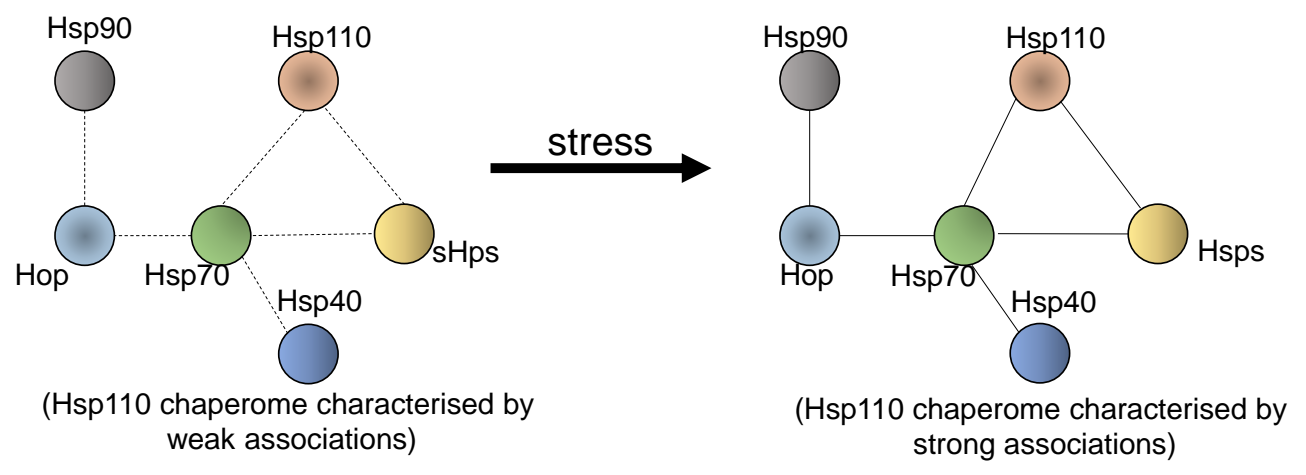

C. Hsp70 monomers

Hsp110 monomers
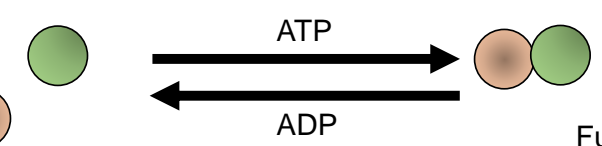

Functional Hsp110/Hsp70 hetero-dimers

Figure 5. Hsp110 as an essential oncogenic proteome regulating chaperome: (A) Hsp110s facilitate exchange of ADP to ATP by canonical Hsp70, allowing release of a folded peptide. (B) Affinity of partners of the Hsp110 chaperome is enhanced by stress. (C) The formation of functional Hsp110:Hsp70 heterodimers is modulated by nucleotides.

Hsp110 is known to directly associate with canonical Hsp70 through NBD-NBD interactions ([44,54,61], Figure 5) to form a heterodimer that facilitates Hsp70-based protein folding. Hsp110 acts a co-chaperone of Hsp70, facilitating the exchange of ADP for ATP state, leading to substrate release from the canonical Hsp70 partner (Figure 5). Given that Hsp70 facilitates the folding of virtually all proteins within the cell [134], the NEF role of Hsp110 in this regard is crucial to the efficient function of canonical Hsp70.

Hsp110s likely play multiple roles in cancer cells, since their chaperone function involves the stabilization of oncogenic proteins and those involved in cancer signaling 
pathways. The emerging role of Hsp110 in immunomodulation has been described [72,92] and in this regard, Hsp110 is thought to trigger inflammatory responses that propagate tumor growth. Thus, Hsp110 may play a role in tumorigenesis through its chaperokine role. It was recently demonstrated that tumors associated with ER-stress relay stress signals to neighboring cells through secretion of soluble mediators, triggering an exaggerated inflammatory response that facilitates tumor progression [135]. Although it is not clear as to whether Grp170 directly contributes to this inflammatory response induced pro-tumor effect, its involvement in this pathway is highly probable.

Previous studies have shown that Hsp110s and Grp170 are immunogenic chaperones $[36,136]$. As such, these chaperones are promising cancer vaccine candidates. In a murine cervical cancer model, Hsp110 was shown to not only improve the antitumor efficacy of cytotoxic T-lymphocyte epitope E7, but it also significantly inhibited tumor growth [137]. In addition, Hsp110 and carbonic anhydrase IX, of which the latter is the renal cell carcinoma-specific tumor protein, were shown to inhibit growth of renal cell carcinoma in mice [138]. This may imply that Hsp110 plays important roles in activating carbonic anhydrase IX. Hsp110-HER2 complex based vaccines were also shown to induce immune protection against spontaneous breast tumors in a transgenic mice model [139]. Grp170-based anticancer immunotherapeutic approaches are beginning to be explored. It has been demonstrated that a complex of Grp170 and tumor protein antigens activated the immune response, leading to inhibition of tumor growth in a melanoma mouse model [140]. Furthermore, mouse prostate cancer cells engineered to effectively secrete Grp170 exhibited enhanced tumor immunogenicity and cytolytic activity of distant tumors [141]. These studies provide evidence of the immunomodulatory roles of Grp170, possibly presenting them as potential vaccine candidates.

Hsp110 was shown to inhibit activation of dendritic cells through scavenger receptor binding [114]. Notably, Hsp110 has been described as the main chaperone involved in colorectal tumorigenesis and the presence of an Hsp110 inactivating mutation is directly associated with a good prognosis [142]. Interestingly, increased Hsp110 expression has been linked to tumor immunosurveillance [72]. A study by Berthenet et al. [72] demonstrated that Hsp110 overexpression in colorectal cancer cells induces the formation of macrophages with an anti-inflammatory profile. Although the precise mechanisms underlying extracellular release of Hsps (active vs. passive) remain speculative, increased Hsp levels are generally observed in the tumor microenvironment [143]. Indeed, several studies have demonstrated the anti-inflammatory role of extracellular Hsps and, depending on their levels, Hsps could either promote inflammation or suppress it [144]. In this regard, Hsp110/Grp170 may thus play a signal transducer role. Although several studies have demonstrated that Hsp110/Grp170 overexpression triggers release of proinflammatory cytokines, the effect of Hsp110 downregulation on the overall cancer cell proteome remains to be explored. A recent study showed that Hsp110 downregulation is detrimental to colon cancer cell proliferation [145]. This study suggests that Hsp110 depletion or inhibition may have detrimental effects on the proteome of the cancer cell.

\section{Could Hsp110/Grp170 Be Targeted in Cancer Therapy?}

Owing to their prominent role as chaperones, Hsp110 and Grp170 could serve as novel chemotherapeutic targets against cancer. Small molecule inhibitors such as polymyxin B $(\mathrm{PMB})$ and epigallocatechin gallate (EGCG) possess great potential in this regard, as they have been successfully used to inhibit the activity of the Plasmodium falciparum Hsp110 in vitro [146]. These two compounds bind to the NBD, thus abrogating the basal ATPase activity of the Hsp110. However, since the holdase chaperone function of Hsp110/Grp170 is not modulated by nucleotides, targeting the Hsp110 NBD using nucleotide mimetics might not interfere with their direct chaperone role. However, the same NBD-targeted drugs may disrupt the NEF function of these chaperones which in turn would adversely impact fold and function of several proteins implicated in cancer development. Selectively targeting the SBD of Hsp110/Grp170 using peptide substrate mimetics may be an alternative ap- 
proach. Two drug candidates targeting the SBD of Hsp70, 2-phenylethynesulfonamide (PES) and the TKD-motif directed peptide inhibitor, cmHsp70.1 have entered the clinical trials stage [147-149]. The design of domain-specific inhibitory compounds may prove useful in Hsp110-targeted anticancer therapy (Figure 6). Since Hsp110/Grp170 functions in co-operation with several other Hsps, its inhibition may impact the folding fate of the protein complement that drives cancer development and progression. In a recent study, Gozzi [145] designed a novel NBD-binding small molecule inhibitor which compromises Hsp110 chaperone function, thereby inhibiting STAT3 phosphorylation and colorectal cancer cell proliferation. There is therefore an urgent need for identification of novel compounds that target Hsp110/Grp170 chaperones in the fight against cancer. Apart from chemical compounds, antibodies and aptamers could alternatively be designed towards abrogating Hsp110/Grp170 functions. In a colon cancer murine model, an Hsp70 monoclonal antibody-based inhibitor, cmHsp70.1, which binds the TKD motif, was shown to significantly reduce tumor weight and improve survival rate [150]. One of the main challenges in the design of anticancer agents is to develop compounds that are safe. The varied proteomic composition of cancer cells compared to normal cells makes the inhibition of Hsps promising in light of their role as custodians of proteostasis.

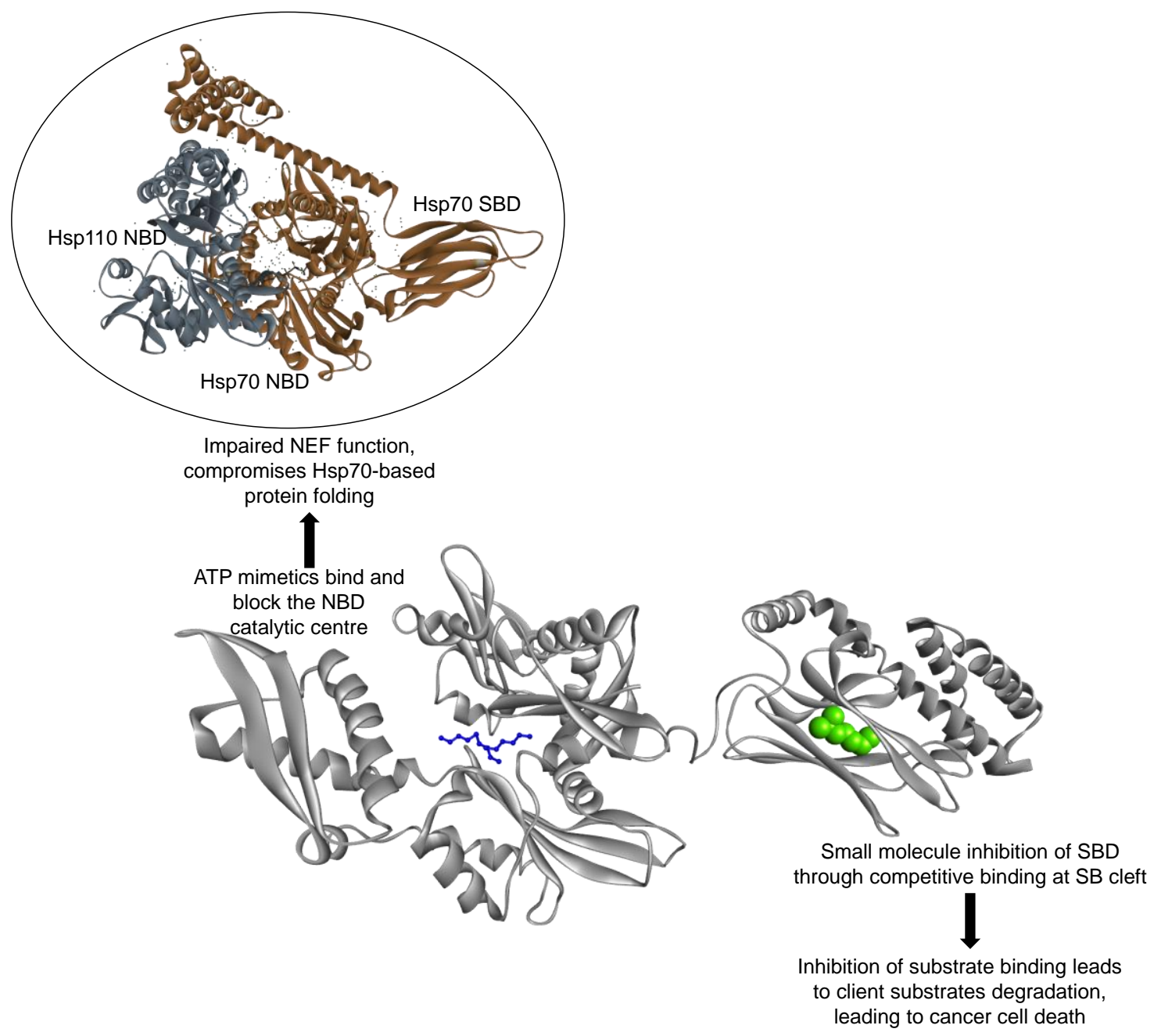

Figure 6. Proposed strategies for targeting Hsp110: Small molecule inhibitors that bind and block the NBD of Hsp110 abrogate its nucleotide exchange function on canonical Hsp70. Peptide mimetics also constitute possible Hsp110 inhibitors that abrogate its chaperone function. 


\section{Conclusions}

Recently, Hsp110/Grp170 chaperones have emerged to a focal point in prospecting for novel chemotherapeutic targets, mainly due to their central roles in both proteostasis and signaling pathways. As nucleotide-independent holdase chaperones, Hsp110/Grp170 are regarded as cellular buffers against proteostatic stress. It is thus not surprising that their role in the cytoprotection of tumor cells, particularly in response to both drug- and hypoxic-stress, is becoming apparent. This review explored the possible interactome of these proteins and established that molecules involved in cancer development are amongst some of their most distinct clientele. This, coupled with their correlated expression with cancer prognosis, suggests a crucial role for these chaperones in cancer development. It is thus envisaged that targeting these group of chaperones has potential as an intervention tool against cancer.

Author Contributions: G.C. and A.S. conceived and wrote the manuscript. Both authors approved the final version of the manuscript. Both authors have read and agreed to the published version of the manuscript.

Funding: G.C. is a recipient of the UCT Faculty of Health Sciences, URC grant. A.S. gratefully acknowledges the Department of Science and Technology/National Research Foundation (NRF) of South Africa for providing funding, grants 75464 and 92598.

Acknowledgments: Figures 1 and 3 were created using Biorender ${ }^{\circledR}$ software.

Conflicts of Interest: The authors have no conflicting interest to declare.

\section{References}

1. Wild, C.P.; Weiderpass, E.; Stewart, B.W. World Cancer Report: Cancer Research for Cancer Prevention; International Agency for Research on Cancer: Lyon, France, 2020.

2. Arruebo, M.; Vilaboa, N.; Saez, B.; Lambea, J.; Tres, A.; Valladares, M.; González-Fernández, Á. Assessment of the evolution of cancer treatment therapies. Cancers 2011, 3, 3279-3330. [CrossRef]

3. Chatterjee, A.; Rodger, E.J.; Eccles, M. Epigenetic drivers of tumorigenesis and cancer metastasis. Semin. Cancer Biol. 2018, 51, 149-159. [CrossRef] [PubMed]

4. Klimczak, M.; Biecek, P.; Zylicz, A.; Zylicz, M. Heat shock proteins create a signature to predict the clinical outcome in breast cancer. Sci. Rep. 2019, 9, 1-15. [CrossRef] [PubMed]

5. Paul, C.; Manero, F.; Gonin, S.; Kretz-Remy, C.; Virot, S.; Arrigo, A.P. Hsp27 as a negative regulator of cytochrome C release. Mol. Cell Biol. 2002, 22, 816-834. [CrossRef] [PubMed]

6. Chauhan, V.P.; Jain, R.K. Strategies for advancing cancer nanomedicine. Nat. Mater. 2013, 12, 958-962. [CrossRef] [PubMed]

7. Voss, O.H.; Batra, S.; Kolattukudy, S.J.; Gonzalez-Mejia, M.E.; Smith, J.B.; Doseff, A.I. Binding of caspase-3 prodomain to heat shock protein 27 regulates monocyte apoptosis by inhibiting caspase-3 proteolytic activation. J. Biol. Chem. 2007, 282, 25088-25099. [CrossRef] [PubMed]

8. Acunzo, J.; Katsogiannou, M.; Rocchi, P. Small heat shock proteins HSP27 (HspB1), $\alpha$ B-crystallin (HspB5) and HSP22 (HspB8) as regulators of cell death. Int. J. Biochem. Cell Biol. 2012, 44, 1622-1631. [CrossRef]

9. Yang, X.; Wang, J.; Zhou, Y.; Wang, Y.; Wang, S.; Zhang, W. Hsp70 promotes chemoresistance by blocking Bax mitochondrial translocation in ovarian cancer cells. Cancer Lett. 2012, 321, 137-143. [CrossRef]

10. Stankiewicz, A.R.; Lachapelle, G.; Foo, C.P.Z.; Radicioni, S.M.; Mosser, D.D. Hsp70 inhibits heat-induced apoptosis ppstream of mitochondria by preventing Bax translocation. J. Biol. Chem. 2005, 280, 38729-38739. [CrossRef]

11. Ischia, J.; So, A.I. The role of heat shock proteins in bladder cancer. Nat. Rev. Urol. 2013, 10, 386-395. [CrossRef]

12. Ferreira, L.M.R.; Cunha-Oliveira, T.; Sobral, M.C.; Abreu, P.L.; Alpoim, M.C.; Urbano, A.M. Impact of carcinogenic chromium on the cellular response to proteotoxic stress. Int. J. Mol. Sci. 2019, 20, 4901. [CrossRef] [PubMed]

13. Ciocca, D.R.; Calderwood, S.K. Heat shock proteins in cancer: Diagnostic, prognostic, predictive, and treatment implications. Cell Stress Chaperones 2005, 10, 86-103. [CrossRef] [PubMed]

14. Calderwood, S.K.; Khaleque, M.A.; Sawyer, D.B.; Ciocca, D.R. Heat shock proteins in cancer: Chaperones of tumorigenesis. Trends Biochem. Sci. 2006, 31, 164-172. [CrossRef] [PubMed]

15. Nahleh, Z.; Tfayli, A.; Najm, A.; El Sayed, A.; Nahle, Z. Heat shock proteins in cancer: Targeting the 'chaperones'. Future Med. Chem. 2012, 4, 927-935. [CrossRef] [PubMed]

16. Dimas, D.T.; Perlepe, C.D.; Sergentanis, T.N.; Misitzis, I.; Kontzoglou, K.; Patsouris, E.; Kouraklis, G.; Psaltopoulou, T.; Nonni, A. The prognostic significance of Hsp70/Hsp90 expression in breast cancer: A systematic review and meta-analysis. Anticancer Res. 2018, 38, 1551-1562. [CrossRef] 
17. Calderwood, S.K.; Stevenson, M.A.; Murshid, A. Heat shock proteins, autoimmunity, and aancer treatment. Autoimmune Dis. 2012, 2012, 1-10. [CrossRef]

18. Yun, C.W.; Kim, H.J.; Lim, J.H.; Lee, S.H. Heat shock proteins: Agents of cancer development and therapeutic targets in anticancer therapy. Cells 2019, 9, 60. [CrossRef]

19. Fan, G.; Tu, Y.; Wu, N.; Xiao, H. The expression profiles and prognostic values of HSPs family members in head and neck cancer. Cancer Cell Int. 2020, 20,1-12. [CrossRef]

20. Gopal, A.; Gopal, U. Cell Surface Heart shock proteins and their role in cancer. Clin. Pathol. 2017, 1, 000104. [CrossRef]

21. Zininga, T.; Ramatsui, L.; Shonhai, A. Heat shock proteins as immunomodulants. Molecules 2018, 23, 2846. [CrossRef]

22. Botzler, C.; Li, G.; Issels, R.D.; Multhoff, G. Definition of extracellular localized epitopes of Hsp70 involved in an NK immune response. Cell Stress Chaperones 1998, 3, 6-11. [CrossRef]

23. Multhoff, G.; Mizzen, L.; Winchester, C.C.; Milner, C.M.; Wenk, S.; Eissner, G.; Kampinga, H.H.; Laumbacher, B.; Johnson, J. Heat shock protein 70 (Hsp70) stimulates proliferation and cytolytic activity of natural killer cells. Exp. Hematol. 1999, 27, 1627-1636. [CrossRef]

24. Wu, X.; Wanders, A.; Wardega, P.; Tinge, B.; Gedda, L.; Bergstrom, S.M.; Sooman, L.; Gullbo, J.; Bergqvist, M.; Hesselius, P.; et al. Hsp90 is expressed and represents a therapeutic target in human oesophageal cancer using the inhibitor 17-allylamino-17demethoxygeldanamycin. Br. J. Cancer 2009, 100, 334-343. [CrossRef] [PubMed]

25. Garg, G.; Khandelwal, A.; Blagg, B.S. Anticancer inhibitors of Hsp90 function: Beyond the usual suspects. Adv. Cancer Res. 2016, 129, 51-88. [PubMed]

26. Chavany, C.; Mimnaugh, E.; Miller, P.; Bitton, R.; Nguyen, P.; Trepel, J.; Whitesell, L.; Schnur, R.; Moyer, J.; Neckers, L. p185erbB2 binds to GRP94 in vivo. Dissociation of the p185erbB2/GRP94 heterocomplex by benzoquinone ansamycins pre-cedes depletion of p185erbB2. Biol. Chem. 1996, 9, 4974-4977. [CrossRef] [PubMed]

27. Yarden, Y.; Sliwkowski, M.X. Untangling the ErbB signaling network. Nat. Rev. Mol. Cell Biol. 2001, 2, 127-137. [CrossRef]

28. Hagn, F.; Lagleder, S.; Retzlaff, M.; Rohrberg, J.; Demmer, O.; Richter, K.W.; Buchner, J.; Kessler, H. Structural analysis of the interaction between Hsp90 and the tumor suppressor protein p53. Nat. Struct. Mol. Biol. 2011, 18, 1086-1093. [CrossRef]

29. Kudryavtsev, V.A.; Khokhlova, A.V.; Mosina, V.A.; Selivanova, E.I.; Kabakov, A.E. Induction of Hsp70 in tumor cells treated with inhibitors of the Hsp90 activity: A predictive marker and promising target for radiosensitization. PLoS ONE 2017, 12, e0173640. [CrossRef]

30. Beere, H.M.; Wolf, B.B.; Cain, K.; Mosser, D.D.; Mahboubi, A.; Kuwana, T.; Tailor, P.; Morimoto, R.I.; Cohen, G.M.; Green, D.R. Heat-shock protein 70 inhibits apoptosis by preventing recruitment of procaspase-9 to the Apaf-1 apoptosome. Nat. Cell Biol. 2000, 2, 469-475. [CrossRef]

31. Ikwegbue, P.C.; Masamba, P.; Oyinloye, B.E.; Kappo, A.P. Roles of heat shock proteins in apoptosis, oxidative stress, human inflammatory diseases, and cancer. Pharmaceuticals 2018, 11, 2. [CrossRef]

32. Venugopal, A.; Stoffel, E.M. Colorectal cancer in young adults. Curr. Treat. Opt. Gastroenterol. 2019, 17, 89-98. [CrossRef] [PubMed]

33. Mosser, D.D.; Morimoto, R.I. Molecular chaperones and the stress of oncogenesis. Oncogene 2004, 23, 2907-2918. [CrossRef] [PubMed]

34. Sherman, M.Y.; Gabai, V.L. Hsp70 in cancer: Back to the future. Oncogene 2015, 34, 4153-4161. [CrossRef]

35. Chen, Y.; Chen, J.; Loo, A.; Jaeger, S.; Bagdasarian, L.; Yu, J.; Chung, F.; Korn, J.; Ruddy, D.; Guo, R.; et al. Targeting HSF1 sensitizes cancer cells to HSP90 inhibition. Oncotarget 2013, 4, 816-829. [CrossRef] [PubMed]

36. Wang, X.; Chen, M.; Zhou, J.; Zhang, X. HSP27, 70 and 90, anti-apoptotic proteins, in clinical cancer therapy. Int. J. Oncol. 2014, 45, 18-30. [CrossRef] [PubMed]

37. Chatterjee, S.; Burns, T.F. Targeting heat shock proteins in cancer: A promising therapeutic approach. Int. J. Mol. Sci. 2017, 18, 1978. [CrossRef] [PubMed]

38. Yaglom, J.A.; Wang, Y.; Li, A.; Li, Z.; Monti, S.; Alexandrov, I.; Lu, X.; Sherman, M.Y. Cancer cell responses to Hsp70 inhibitor JG-98: Comparison with Hsp90 inhibitors and finding synergistic drug combinations. Sci. Rep. 2018, 8, 1-12. [CrossRef]

39. Yin, F.; Feng, F.; Wang, L.; Wang, X.; Li, Z.; Cao, Y. SREBP-1 inhibitor Betulin enhances the antitumor effect of Sorafenib on hepatocellular carcinoma via restricting cellular glycolytic activity. Cell Death Dis. 2019, 10, 1-12. [CrossRef] [PubMed]

40. Kampinga, H.H.; Hageman, J.; Vos, M.J.; Kubota, H.; Tanguay, R.M.; Bruford, E.A.; Cheetham, M.E.; Chen, B.; Hightower, L.E. Guidelines for the nomenclature of the human heat shock proteins. Cell Stress Chaperones 2008, 14, 105-111. [CrossRef]

41. Easton, D.P.; Kaneko, Y.; Subjeck, J.R. The Hsp110 and Grp170 stress proteins: Newly recognized relatives of the Hsp70s. Cell Stress Chaperones 2000, 5, 276-290. [CrossRef]

42. Chakafana, G.; Zininga, T.; Shonhai, A. Comparative structure-function features of Hsp70s of Plasmodium falciparum and human origins. Biophys. Rev. 2019, 11, 591-602. [CrossRef] [PubMed]

43. Oh, H.J.; Easton, D.; Murawski, M.; Kaneko, Y.; Subjeck, J.R. The chaperoning activity of hsp110 identification of functional domains by use of targeted deletions. J. Biol. Chem. 1999, 274, 15712-15718. [CrossRef]

44. Zininga, T.; Achilonu, I.; Hoppe, H.C.; Prinsloo, E.; Dirr, H.W.; Shonhai, A. Plasmodium falciparum Hsp70-z, an Hsp110 homologue, exhibits independent chaperone activity and interacts with Hsp70-1 in a nucleotide-dependent fashion. Cell Stress Chaperones 2016, 21, 499-513. [CrossRef] [PubMed]

45. Chakafana, G.; Zininga, T.; Shonhai, A. The link that binds: The linker of Hsp70 as a helm of the protein's function. Biomolecules 2019, 9, 543. [CrossRef] [PubMed]

46. Zappasodi, R.; Ruggiero, G.; Guarnotta, C.; Tortoreto, M.; Tringali, C.; Cavanè, A.; Cabras, A.D.; Castagnoli, L.; Venerando, B.; Zaffaroni, N.; et al. HSPH1 inhibition downregulates Bcl-6 and c-Myc and hampers the growth of human aggressive B-cell non-Hodgkin lymphoma. Blood 2015, 125, 1768-1771. [CrossRef] [PubMed] 
47. Takahashi, H.; Furukawa, T.; Yano, T.; Sato, N.; Takizawa, J.; Kurasaki, T.; Abe, T.; Narita, M.; Masuko, M.; Koyama, S.; et al. Identification of an overexpressed gene, HSPA4L, the product of which can provoke prevalent humoral immune responses in leukemia patients. Exp. Hematol. 2007, 35, 1091-1099. [CrossRef]

48. Held, T.; Barakat, A.Z.; Mohamed, B.A.; Paprotta, I.; Meinhardt, A.; Engel, W.; Adham, I.M. Heat-shock protein HSPA4 is required for progression of spermatogenesis. Reproduction 2011, 142, 133-144. [CrossRef]

49. Behnke, J.; Mann, M.J.; Scruggs, F.-L.; Feige, M.J.; Hendershot, L.M. Members of the Hsp70 Family Recognize Distinct Types of Sequences to Execute ER Quality Control. Mol. Cell 2016, 63, 739-752. [CrossRef]

50. Xu, X.; Sarbeng, E.B.; Vorvis, C.; Kumar, D.P.; Zhou, L.; Liu, Q. Unique peptide substrate binding properties of 110-kDa heat-shock protein (Hsp110) determine its distinct chaperone activity. J. Biol. Chem. 2012, 287, 5661-5672. [CrossRef]

51. Li, H.; Zhu, H.; Sarbeng, E.B.; Liu, Q.; Tian, X.; Yang, Y.; Lyons, C.; Zhou, L.; Liu, Q. An unexpected second binding site for polypeptide substrates is essential for Hsp70 chaperone activity. J. Biol. Chem. 2020, 295, 584-596. [CrossRef]

52. Mabate, B.; Zininga, T.; Ramatsui, L.; Makumire, S.; Achilonu, I.; Dirr, H.W.; Shonhai, A. Structural and biochemical characterization of Plasmodium falciparum Hsp70-x reveals functional versatility of its C-terminal EEVN motif. Proteins 2018, 86, 1189-1201. [CrossRef] [PubMed]

53. Goeckeler, J.L.; Petruso, A.P.; Aguirre, J.; Clement, C.C.; Chiosis, G.; Brodsky, J.L. The yeast Hsp110, Sse1p, exhibits high-affinity peptide binding. FEBS Lett. 2008, 582, 2393-2396. [CrossRef]

54. Dragovic, Z.; Broadley, S.A.; Shomura, Y.; Bracher, A.; Hartl, F.U. Molecular chaperones of the Hsp110 family act as nucleotide exchange factors of Hsp70s. EMBO J. 2006, 25, 2519-2528. [CrossRef] [PubMed]

55. Velasco, L.; Dublang, L.; Moro, F.; Muga, A. The complex phosphorylation patterns that regulate the activity of Hsp70 and its cochaperones. Int. J. Mol. Sci. 2019, 20, 4122. [CrossRef] [PubMed]

56. Mattoo, R.U.; Farina Henriquez Cuendet, A.; Subanna, S.; Finka, A.; Priya, S.; Sharma, S.K.; Goloubinoff, P. Synergism between a foldase and an unfoldase: Reciprocal dependence between the thioredoxin-like activity of DnaJ and the polypeptide-unfolding activity of DnaK. Front. Mol. Biosci. 2014, 1, 7. [CrossRef]

57. Mogk, A.; Kummer, E.; Bukau, B. Cooperation of Hsp70 and Hsp100 chaperone machines in protein disaggregation. Front. Mol. Biosci. 2015, 2, 22. [CrossRef]

58. Shonhai, A.; Boshoff, A.; Blatch, G.L. The structural and functional diversity of Hsp70 proteins from Plasmodium falciparum. Protein Sci. 2007, 16, 1803-1818. [CrossRef]

59. Kampinga, H.H.; Bergink, S. Heat shock proteins as potential targets for protective strategies in neurodegeneration. Lancet Neurol. 2016, 15, 748-759. [CrossRef]

60. Garcia, V.M.; Nillegoda, N.B.; Bukau, B.; Morano, K.A. Substrate binding by the yeast Hsp110 nucleotide exchange factor and molecular chaperone Sse1 is not obligate for its biological activities. Mol. Biol. Cell 2017, 28, 2066-2075. [CrossRef]

61. Polier, S.; Dragovic, Z.; Hartl, F.U.; Bracher, A. Structural basis for the cooperation of Hsp70 and Hsp110 chaperones in protein folding. Cell 2008, 133, 1068-1079. [CrossRef]

62. Moenner, M.; Pluquet, O.; Bouchecareilh, M.; Chevet, E. Integrated endoplasmic reticulum stress responses in cancer. Cancer Res 2007, 67, 10631-10634. [CrossRef] [PubMed]

63. Oakes, R.S.; Bushnell, G.G.; Orbach, S.M.; Kandagatla, P.; Zhang, Y.; Morris, A.H.; Hall, M.S.; Lafaire, P.; Decker, J.T.; Hartfield, R.M.; et al. Metastatic conditioning of myeloid cells at a subcutaneous synthetic niche reflects disease progression and predicts pherapeutic outcomes. Cancer Res. 2020, 80, 602-612. [CrossRef] [PubMed]

64. Viale, A.; Draetta, G.F. Sugar? No Thank You, just a deep breath of oxygen for cancer stem cells. Cell Metab. 2015, 22, 543-545. [CrossRef] [PubMed]

65. Zininga, T.; Achilonu, I.; Hoppe, H.C.; Prinsloo, E.; Dirr, H.W.; Shonhai, A. Overexpression, purification and characterisation of the Plasmodium falciparum Hsp70-z (PfHsp70-z) protein. PLoS ONE 2015, 10, e0129445. [CrossRef] [PubMed]

66. Kumar, V.; Peter, J.J.; Sagar, A.; Ray, A.; Jha, M.P.; Rebeaud, M.; Tiwari, S.; Goloubinoff, P.; Ashish, F.; Mapa, K. Interdomain communication suppressing high intrinsic ATPase activity of Sse1 is essential for its co-disaggregase activity with Ssa1. FEBS J. 2019, 287, 671-694. [CrossRef] [PubMed]

67. Gotoh, K.; Nonoguchi, K.; Higashitsuji, H.; Kaneko, Y.; Sakurai, T.; Sumitomo, Y.; Itoh, K.; Subjeck, J.R.; Fujita, J. Apg-2 has a chaperone-like activity similar to Hsp110 and is overexpressed in hepatocellular carcinomas. FEBS Lett. 2004, 560, 19-24. [CrossRef]

68. Ullmann, R.; Morbini, P.; Halbwedl, I.; Bongiovanni, M.; Gogg-Kammerer, M.; Papotti, M.; Gabor, S.; Renner, H.; Popper, H.H. Protein expression profiles in adenocarcinomas and squamous cell carcinomas of the lung generated using tissue microarrays. $J$. Pathol. 2004, 203, 798-807. [CrossRef]

69. Muchemwa, F.C.; Nakatsura, T.; Fukushima, S.; Nishimura, Y.; Kageshita, T.; Ihn, H. Differential expression of heat shock protein 105 in melanoma and melanocytic naevi. Melanoma Res. 2008, 18, 166-171. [CrossRef]

70. Chan, D.S.M.; Lau, R.; Aune, D.; Vieira, R.; Greenwood, D.C.; Kampman, E.; Norat, T. Red and Processed Meat and Colorectal Cancer Incidence: Meta-Analysis of Prospective Studies. PLoS ONE 2011, 6, e20456. [CrossRef] [PubMed]

71. Kimura, A.; Ogata, K.; Altan, B.; Yokobori, T.; Ide, M.; Mochiki, E.; Toyomasu, Y.; Kogure, N.; Yanoma, T.; Suzuki, M.; et al. Nuclear heat shock protein 110 expression is associated with poor prognosis and chemotherapy resistance in gastric cancer. Oncotarget 2016, 7, 18415. [CrossRef]

72. Berthenet, K.; Bokhari, A.; Lagrange, A.; Marcion, G.; Boudesco, C.; Causse, S.; De Thonel, A.; Svrcek, M.; Goloudina, A.R.; Dumont, S.; et al. HSP110 promotes colorectal cancer growth through STAT3 activation. Oncogene 2017, 36, 2328-2336. [CrossRef] [PubMed] 
73. Chan, A.T. Turning up the heat on colorectal cancer. Nat. Med. 2011, 17, 1186-1188. [CrossRef]

74. Duval, A.; Collura, A.; Berthenet, K.; Lagrange, A.; Garrido, C. Microsatellite instability in colorectal cancer: Time to stop hiding! Oncotarget 2011, 2, 826-827. [CrossRef] [PubMed]

75. Taguchi, K.; Watanabe, Y.; Tsujimura, A.; Tanaka, M. Expression of $\alpha$-synuclein is regulated in a neuronal cell type-dependent manner. Anat. Sci. Int. 2018, 94, 11-22. [CrossRef]

76. Ge, Y.; Xu, K. Alpha-synuclein contributes to malignant progression of human meningioma via the Akt/mTOR path-way. Cancer Cell Int. 2016, 16, 1-7. [CrossRef] [PubMed]

77. Yu, N.; Kakunda, M.; Pham, V.; Lill, J.R.; Du, P.; Wongchenko, M.J.; Yan, Y.; Firestein, R.; Huang, X. HSP105 recruits protein phosphatase 2A to dephosphorylate $\beta$-catenin. Mol. Cell. Biol. 2015, 35, 1390-1400. [CrossRef]

78. Kai, M.; Nakatsura, T.; Egami, H.; Senju, S.; Nishimura, Y.; Ogawa, M. Heat shock protein 105 is overexpressed in a variety of human tumors. Oncol. Rep. 2003, 10, 1777-1782. [CrossRef]

79. Skrzypczak, M.; Goryca, K.; Rubel, T.; Paziewska, A.; Mikula, M.; Jarosz, D.; Pachlewski, J.; Oledzki, J.; Ostrowsk, J. Modeling oncogenic signaling in colon tumors by multidirectional analyses of microarray data directed for maximization of analytical reliability. PLoS ONE 2010, 5, e13091. [CrossRef]

80. Yu, H.; Pardoll, D.M.; Jove, R. STATs in cancer inflammation and immunity: A leading role for STAT3. Nat. Rev. Cancer 2009, 9 , 798-809. [CrossRef]

81. Kamran, M.Z.; Patil, P.; Gude, R.P. Role of STAT3 in cancer metastasis and translational advances. BioMed Res. Int. 2013, 2013, 421821. [CrossRef]

82. Lakkim, V.; Reddy, M.C.; Prasad, D.V.R.; Lomada, D. Role of STAT3 in colorectal cancer development. In Role of Transcription Factors in Gastrointestinal Malignancies; Springer Nature: Singapore, 2017; pp. 269-298.

83. Ma, J.-H.; Qin, L.; Li, X. Role of STAT3 signaling pathway in breast cancer. Cell Commun. Signal. 2020, 18, 1-13. [CrossRef] [PubMed]

84. Yuan, J.; Zhang, F.; Niu, R. Multiple regulation pathways and pivotal biological functions of STAT3 in cancer. Sci. Rep. 2016, 5, 17663. [CrossRef] [PubMed]

85. Hu, F.; Li, G.; Huang, C.; Hou, Z.; Yang, X.; Luo, X.; Feng, Y.; Wang, G.; Hu, J.-B.; Cao, Z. The autophagy-independent role of BECN1 in colorectal cancer metastasis through regulating STAT3 signaling pathway activation. Cell Death Dis. 2020, 11, 1-13. [CrossRef] [PubMed]

86. Zuo, D.; Subjeck, J.; Wang, X.Y. Unfolding the role of large heat shock proteins: New insights and therapeutic implications. Front. Immunol. 2016, 7, 75. [CrossRef] [PubMed]

87. Hosaka, S.; Nakatsura, T.; Tsukamoto, H.; Hatayama, T.; Baba, H.; Nishimura, Y. Synthetic small interfering RNA targeting heat shock protein 105 induces apoptosis of various cancer cells both in vitro and in vivo. Cancer Sci. 2006, 97, 623-632. [CrossRef]

88. Entschladen, F.; Drell, T.L.; Lang, K.; Joseph, J.; Zaenker, K.S. Tumor-cell migration, invasion, and metastasis: Navigation by neurotransmitters. Lancet Oncol. 2004, 5, 254-258. [CrossRef]

89. Spano, D.; Heck, C.; De Antonellis, P.; Christofori, G.; Zollo, M. Molecular networks that regulate cancer metastasis. Semin. Cancer Biol. 2012, 22, 234-249. [CrossRef]

90. Van Zijl, F.; Krupitza, G.; Mikulits, W. Initial steps of metastasis: Cell invasion and endothelial transmigration. Mutat. Res. Mutat. Res. 2011, 728, 23-34. [CrossRef]

91. De Matteis, S.; Canale, M.; Verlicchi, A.; Bronte, G.; Delmonte, A.; Crinò, L.; Martinelli, G.; Ulivi, P. Advances in molecular mechanisms and immunotherapy involving the immune cell-promoted epithelial-to-mesenchymal transition inlung cancer. J. Oncol. 2019, 2019, 7475364. [CrossRef]

92. Manjili, M.H.; Park, J.; Facciponte, J.G.; Subjeck, J.R. HSP110 induces “danger signals" upon interaction with antigen presenting cells and mouse mammary carcinoma. Immunobiology 2005, 210, 295-303. [CrossRef]

93. Gao, P.; Sun, X.; Chen, X.; Subjeck, J.; Wang, X.-Y. Secretion of stress protein grp170 promotes immune-mediated inhibition of murine prostate tumor. Cancer Immunol. Immunother. 2009, 58, 1319-1328. [CrossRef] [PubMed]

94. Che, D.; Zhang, S.; Jing, Z.; Shang, L.; Jin, S.; Liu, F.; Shen, J.; Li, Y.; Hu, J.; Meng, Q.; et al. Macrophages induce EMT to promote invasion of lung cancer cells through the IL-6-mediated COX-2/PGE2/ $\beta$-catenin signaling pathway. Mol. Immunol. 2017, 90, 197-210. [CrossRef] [PubMed]

95. Browning, L.; Patel, M.R.; Horvath, E.B.; Tawara, K.; Jorcyk, C.L. IL-6 and ovarian cancer: Inflammatory cytokines in promotion of metastasis. Cancer Manag. Res. 2018, 10, 6685-6693. [CrossRef] [PubMed]

96. Lamouille, S.; Xu, J.; Derynck, R. Molecular mechanisms of epithelial-mesenchymal transition. Nat. Rev. Mol. Cell Biol. 2014, 15, 178-196. [CrossRef]

97. Safa, A.R. Epithelial-mesenchymal transition: A hallmark in pancreatic cancer stem cell migration, metastasis formation, and drug resistance. J. Cancer Metastasis Treat. 2020. [CrossRef]

98. Lee, T.K.; Poon, R.T.P.; Yuen, A.P.; Ling, M.T.; Kwok, W.K.; Wang, X.H.; Wong, Y.C.; Guan, X.Y.; Man, K.; Chau, K.L.; et al. Twist overexpression correlates with hepatocel-lular carcinoma metastasis through induction of epithelial-mesenchymal transition. Clin. Cancer Res. 2006, 12, 5369-5376. [CrossRef]

99. Hugo, H.; Ackland, M.L.; Blick, T.; Lawrence, M.G.; Clements, J.A.; Williams, E.D.; Thompson, E.W. Epithelial-mesenchymal and mesenchymal-epithelial transitions in carcinoma progression. J. Cell Physiol. 2007, 213, 374-383. [CrossRef]

100. Duennwald, M.L.; Echeverria, A.; Shorter, J. Small heat shock proteins potentiate amyloid dissolution by protein disaggregases from yeast and humans. PLoS Biol. 2012, 10, e1001346. [CrossRef] 
101. Zhao, M.; Shen, F.; Yin, Y.X.; Yang, Y.Y.; Xiang, D.J.; Chen, Q. Increased expression of heat shock protein 27 correlates with peritoneal metastasis in epithelial ovarian cancer. Reprod. Sci. 2012, 19, 748-753. [CrossRef]

102. Lopez-Soto, A.; Gonzalez, S.; Smyth, M.J.; Galluzzi, L. Control of metastasis by NK Cells. Cancer Cell 2017, 32, 135-154. [CrossRef]

103. Komuro, A.; Yashiro, M.; Iwata, C.; Morishita, Y.; Johansson, E.; Matsumoto, Y.; Watanabe, A.; Aburatani, H.; Miyoshi, H.; Kiyono, K.; et al. Diffuse-type gastric carcinoma: Progression, angiogenesis, and transforming growth factor $\beta$ signaling. J. Natl. Cancer Inst. 2009, 101, 592-604. [CrossRef] [PubMed]

104. Huang, C.; Li, Z.; Li, N.; Li, Y.; Chang, A.; Zhao, T.; Wang, X.; Wang, H.; Gao, S.; Yang, S.; et al. Interleukin 35 expression correlates with microvessel density in pancreatic ductal adenocarcinoma, recruits monocytes, and promotes growth and angiogenesis of xenograft tumors in mice. Gastroenterology 2018, 154, 675-688. [CrossRef] [PubMed]

105. Borges, T.J.; Wieten, L.; Van Herwijnen, M.J.C.; Broere, F.; Van Der Zee, R.; Bonorino, C.; Van Eden, W. The anti-inflammatory mechanisms of Hsp70. Front. Immunol. 2012, 3, 95. [CrossRef] [PubMed]

106. Hatayama, T.; Yamagishi, N.; Minobe, E.; Sakai, K. Role of hsp105 in protection against stress-induced apoptosis in neuronal PC12 cells. Biochem. Biophys. Res. Commun. 2001, 288, 528-534. [CrossRef]

107. Yamagishi, N.; Ishihara, K.; Saito, Y.; Hatayama, T. Hsp105 family proteins suppress staurosporine-induced apoptosis by inhibiting the translocation of Bax to mitochondria in HeLa cells. Exp. Cell Res. 2006, 312, 3215-3223. [CrossRef]

108. Boudesco, C.; Verhoeyen, E.; Martin, L.; Chassagne-Clement, C.; Salmi, L.; Mhaidly, R.; Pangault, C.; Fest, T.; Ramla, S.; Jardin, F.; et al. HSP110 sustains chronic NF-KB signaling in activated B-cell diffuse large B-cell lymphoma through MyD88 stabilization. Blood 2018, 132, 510-520. [CrossRef]

109. Park, J.; Easton, D.; Chen, X.; Macdonald, I.J.; Wang, X.-Y.; Subjeck, J.R. The Chaperoning properties of mouse Grp170, a member of the third family of Hsp70 related proteins. Biochemistry 2003, 42, 14893-14902. [CrossRef]

110. Behnke, J.; Hendershot, L.M. The large Hsp70 Grp170 binds to unfolded protein substrates in vivo with a regulation distinct from conventional Hsp70s. J. Biol. Chem. 2014, 289, 2899-2907. [CrossRef]

111. Lee, A.S. Glucose-regulated proteins in cancer: Molecular mechanisms and therapeutic potential. Nat. Rev. Cancer 2014, 14, 263-276. [CrossRef]

112. Tsukamoto, Y.; Kuwabara, K.; Hirota, S.; Kawano, K.; Yoshikawa, K.; Ozawa, K.; Kobayashi, T.; Yanagi, H.; Stern, D.M.; Tohyama, M.; et al. Expression of the 150-kd oxygen-regulated protein in human breast cancer. Lab. Investig. 1998, 78, 699-706.

113. Stojadinovic, A.; Hooke, J.A.; Shriver, C.D.; Nissan, A.; Kovatich, A.J.; Kao, T.C. HYOU1/Orp150 expression in breast cancer. Med. Sci. Monit. 2007, 13, BR231-BR239. [PubMed]

114. Facciponte, J.G.; Wang, X.-Y.; Subjeck, J.R. Hsp110 and Grp170, members of the Hsp70 superfamily, bind to scavenger receptor-A and scavenger receptor expressed by endothelial cells-I. Eur. J. Immunol. 2007, 37, 2268-2279. [CrossRef] [PubMed]

115. Ozawa, K.; Kuwabara, K.; Tamatani, M.; Takatsuji, K.; Tsukamoto, Y.; Kaneda, S.; Yanagi, H.; Stern, D.M.; Eguchi, Y.; Tsujimoto, Y.; et al. 150-kDa oxygen-regulated protein (ORP150) suppresses hypoxia-induced apoptotic cell death. J. Biol. Chem. 1999, 274, 6397-6404. [CrossRef] [PubMed]

116. Ozawa, K.; Tsukamoto, Y.; Hori, O.; Kitao, Y.; Yanagi, H.; Stern, D.M.; Ogawa, S. Regulation of tumor angiogenesis by oxygenregulated protein 150, an inducible endoplasmic reticulum chaperone. Cancer Res. 2001, 61, 4206-4213.

117. Miyagi, T.; Hori, O.; Koshida, K.; Egawa, M.; Kato, H.; Kitagawa, Y.; Ozawa, K.; Ogawa, S.; Namiki, M. Antitumor effect of reduction of 150-kDa oxygen-regulated protein expression on human prostate cancer cells. Int. J. Urol. 2002, 9, 577-585. [CrossRef]

118. Asahi, H.; Koshida, K.; Hori, O.; Ogawa, S.; Namiki, M. Immunohistochemical detection of the 150-kDa oxygen-regulated protein in bladder cancer. BJU Int. 2002, 90, 462-466. [CrossRef]

119. Szklarczyk, D.; Morris, J.H.; Cook, H.; Kuhn, M.; Wyder, S.; Simonovic, M.; Santos, A.; Doncheva, N.T.; Roth, A.; Bork, P.; et al. The STRING database in 2017: Quality-controlled protein-protein association networks, made broadly accessible. Nucleic Acids Res. 2017, 45, D362-D368. [CrossRef]

120. Ray, M.R.; Wafa, L.A.; Cheng, H.; Snoek, R.; Fazli, L.; Gleave, M.; Rennie, P.S. Cyclin G-associated kinase: A novel androgen receptor-interacting transcriptional coactivator that is overexpressed in hormone refractory prostate cancer. Int. J. Cancer 2005, 118, 1108-1119. [CrossRef]

121. Dolly, S.O.; Gurden, M.D.; Drosopoulos, K.; Clarke, P.; De Bono, J.; Kaye, S.; Workman, P.; Linardopoulos, S. RNAi screen reveals synthetic lethality between cyclin G-associated kinase and FBXW7 by inducing aberrant mitoses. Br. J. Cancer 2017, 117, 954-964. [CrossRef]

122. Wente, S.R.; Rout, M.P. The Nuclear Pore Complex and Nuclear Transport. Cold Spring Harb. Perspect. Biol. 2010, 2, a000562. [CrossRef]

123. Köhler, A.; Hurt, E. Gene regulation by nucleoporins and links to cancer. Mol. Cell 2010, 38, 6-15. [CrossRef]

124. Rodriguez-Bravo, V.; Pippa, R.; Song, W.-M.; Carceles-Cordon, M.; Dominguez-Andres, A.; Fujiwara, N.; Woo, J.; Koh, A.P.; Ertel, A.; Lokareddy, R.K.; et al. Nuclear pores promote lethal prostate cancer by increasing POM121-driven E2F1, MYC, and AR nuclear import. Cell 2018, 174, 1200-1215. [CrossRef] [PubMed]

125. Ma, H.; Li, L.; Jia, L.; Gong, A.; Wang, A.; Zhang, L.; Gu, M.; Tang, G. POM121 is identified as a novel prognostic marker of oral squamous cell carcinoma. J. Cancer 2019, 10, 4473-4480. [CrossRef] [PubMed]

126. Nofrini, V.; Di Giacomo, D.; Mecucci, C. Nucleoporin genes in human diseases. Eur. J. Hum. Genet 2016, 24, 1388-1395. [CrossRef] [PubMed]

127. Han, Z.-J.; Feng, Y.-H.; Gu, B.-H.; Li, Y.-M.; Chen, H. The post-translational modification, SUMOylation, and cancer (Review). Int. J. Oncol. 2018, 52, 1081-1094. [CrossRef] [PubMed] 
128. Linxweiler, J.; Körbel, C.; Müller, A.; Jüngel, E.; Blaheta, R.; Heinzelmann, J.; Stöckle, M.; Junker, K.; Menger, M.D.; Saar, M. Experimental imaging in orthotopic renal cell carcinoma xenograft models: Comparative evaluation of high-resolution 3D ultrasonography, in-vivo micro-CT and 9.4T MRI. Sci. Rep. 2017, 7, 14249. [CrossRef]

129. Diwadkar-Navsariwala, V.; Prins, G.S.; Swanson, S.M.; Birch, L.A.; Ray, V.H.; Hedayat, S.; Lantvit, D.L.; Diamond, A.M. Selenoprotein deficiency accelerates prostate carcinogenesis in a transgenic model. Proc. Natl. Acad. Sci. USA 2006, 103, 8179-8184. [CrossRef]

130. Tomala, K.; Korona, R. Molecular chaperones and selection against mutations. Biol. Direct. 2008, 3, 5. [CrossRef]

131. Joshi, S.; Wang, T.; Araujo, T.L.S.; Sharma, S.; Brodsky, J.L.; Chiosis, G. Adapting to stress-Chaperome networks in cancer. Nat. Rev. Cancer 2018, 18, 562-575. [CrossRef]

132. Pillarsetty, N.; Jhaveri, K.; Taldone, T.; Caldas-Lopes, E.; Punzalan, B.; Joshi, S.; Bolaender, A.; Uddin, M.M.; Rodina, A.; Yan, P.; et al. Paradigms for precision medicine in epichaperome cancer therapy. Cancer Cell 2019, 36, 559-573. [CrossRef]

133. Yan, P.; Patel, H.J.; Sharma, S.; Corben, A.; Wang, T.; Panchal, P.; Yang, C.; Sun, W.; Araujo, T.L.; Rodina, A.; et al. Molecular stressors engender protein connectivity dysfunction through aberrant N-glycosylation of a chaperone. Cell Rep. 2020, 31, 107840. [CrossRef]

134. Rosenzweig, R.; Sekhar, A.; Nagesh, J.; Kay, L.E. Promiscuous binding by Hsp70 results in conformational heterogeneity and fuzzy chaperone-substrate ensembles. eLife 2017, 14, e28030. [CrossRef] [PubMed]

135. Salminen, A.; Kaarniranta, K.; Kauppinen, A. Exosomal vesicles enhance immunosuppression in chronic inflammation: Impact in cellular senescence and the aging process. Cell. Signal. 2020, 75, 109771. [CrossRef] [PubMed]

136. Wang, X.-Y.; Subjeck, J.R. High molecular weight stress proteins: Identification, cloning and utilisation in cancer immunotherapy. Int. J. Hyperth. 2013, 29, 364-375. [CrossRef] [PubMed]

137. Ren, F.; Xu, Y.; Mao, L.; Ou, R.; Ding, Z.; Zhang, X.; Tang, J.; Li, B.; Jia, Z.; Tian, Z.; et al. Heat shock protein 110 improves the anti-tumor effects of the cytotoxic T lymphocyte epitope E7 in mice. Cancer Biol. 2010, 9, 134-141. [CrossRef]

138. Wang, X.; Tang, S.; Le, S.Y.; Lu, R.; Rader, J.S.; Meyers, C.; Zheng, Z.M. Aberrant expression of oncogenic and tumour-suppressive microRNAs in cervical cancer is required for cancer cell growth. PLoS ONE 2008, 3, e2557.

139. Manjili, M.H.; Wang, X.Y.; Chen, X.; Martin, T.; Repasky, E.A.; Henderson, R.; Subjeck, J.R. HSP110-HER2/neu chaperone complex vaccine induces protective immunity against spontaneous mammary tumors in HER-2/neu transgenic mice. J. Immunol. 2003, 171, 4054-4061. [CrossRef]

140. Wang, X.Y.; Kazim, L.; Repasky, E.A.; Subjeck, J.R. Immunization with tumor-derived ER chaperone grp170 elicits tumor-specific CD8+ T-cell responses and reduces pulmonary metastatic disease. Int. J. Cancer 2003, 105, 226-231. [CrossRef]

141. Gao, P.; Sun, X.; Chen, X.; Wang, Y.; Foster, B.A.; Subjeck, J.; Fisher, P.B.; Wang, X.Y. Secretable chaperone Grp170 enhances therapeutic activity of a novel tumor suppressor, mda-7/IL-24. Cancer Res. 2008, 68, 3890-3898. [CrossRef]

142. Dorard, C.; De Thonel, A.; Collura, A.; Marisa, L.; Svrcek, M.; Lagrange, A.; Jego, G.; Wanherdrick, K.; Joly, A.L.; Buhard, O.; et al. Expression of a mutant HSP110 sensitizes colorectal cancer cells to chemotherapy and improves disease prognosis. Nat. Med. 2011, 17, 1283-1289. [CrossRef]

143. Lang, B.J.; Guerrero-Giménez, M.E.; Prince, T.L.; Ackerman, A.; Bonorino, C.; Calderwood, S.K. Heat Shock Proteins are essential components in transformation and tumor progression: Cancer cell intrinsic pathways and beyond. Int. J. Mol. Sci. 2019, 20, 4507. [CrossRef] [PubMed]

144. Zininga, T.; Shonhai, A. Small molecule inhibitors targeting the heat shock protein system of human obligate protozoan parasites. Int. J. Mol. Sci. 2019, 20, 5930. [CrossRef] [PubMed]

145. Gozzi, G.J.; Gonzalez, D.; Boudesco, C.; Dias, A.M.M.; Gotthard, G.; Uyanik, B.; Dondaine, L.; Marcion, G.; Hermetet, F.; Denis, C.; et al. Selecting the first chemical molecule inhibitor of HSP110 for colorectal cancer therapy. Cell Death Differ. 2020, 27, 117-129. [CrossRef] [PubMed]

146. Zininga, T.; Ramatsui, L.; Makhado, P.B.; Makumire, S.; Achilonu, I.; Hoppe, H.C.; Dirr, H.W.; Shonhai, A. (-)-Epigallocatechin-3gallate inhibits the chaperone activity of Plasmodium falciparum Hsp70 chaperones and abrogates their association with functional partners. Molecules 2017, 22, 2139. [CrossRef] [PubMed]

147. Krause, S.W.; Gastpar, R.; Andreesen, R.; Gross, C.; Ullrich, H.; Thonigs, G.; Pfister, K.; Multhoff, G. Treatment of colon and lung cancer patients with ex vivo heat shock protein 70-peptide-activated, autologous natural killer cells. Clin. Cancer Res. 2004, 10, 3699-3707. [CrossRef] [PubMed]

148. Solit, D.B.; Ivy, S.P.; Kopil, C.; Sikorski, R.; Morris, M.J.; Slovin, S.F.; Kelly, W.K.; DeLaCruz, A.; Curley, T.; Heller, G.; et al. Phase I trial of 17-allylamino-17-demethoxygeldanamycin in patients with advanced cancer. Clin. Cancer Res. 2007, 13, 1775-1782. [CrossRef]

149. Hendriks, L.E.L.; Dingemans, A.M.C. Heat shock protein antagonists in early stage clinical trials for NSCLC. Expert. Opin. Investig. Drugs 2017, 26, 541-550. [CrossRef]

150. Stangl, S.; Gehrmann, M.; Riegger, J.; Kuhs, K.; Riederer, I.; Sievert, W.; Hube, K.; Mocikat, R.; Dressel, R.; Kremmer, E. Targeting membrane heat-shock protein 70 (Hsp70) on tumors by cmHsp70.1 antibody. Proc. Natl. Acad. Sci. USA 2011, 108, 733-738. [CrossRef] 